\title{
Land use planning in the Amazon basin: challenges from resilience thinking
}

\author{
Cesar A. Ruiz Agudelo ${ }^{1}$, Nestor Mazzeo $^{2,3}, \underline{\text { Ismael Díaz }}^{3}$, Maria P. Barral $^{4,5}$, Gervasio Piñeiro $^{6}$, Isabel Gadino $^{3}$, Ingid Roche $^{3}$ \\ and Rocio Juliana Acuña-Posada ${ }^{7}$
}

\begin{abstract}
Amazonia is under threat. Biodiversity and redundancy loss in the Amazon biome severely limits the long-term provision of key ecosystem services in diverse spatial scales (local, regional, and global). Resilience thinking attempts to understand the mechanisms that ensure a system's capacity to recover in the face of external pressures, trauma, or disturbances, as well as changes in its internal dynamics. Resilience thinking also promotes relevant transformations of system configurations considered adverse or nonsustainable, and therefore proposes the simultaneous analysis of the adaptive capacity and the transformation of a system. In this context, seven principles have been proposed, which are considered crucial for social-ecological systems to become resilient. These seven principles of resilience thinking are analyzed in terms of the land use planning and land management of the Amazonian biome. To comprehend its main conflicts, challenges, and opportunities, we reveal the key aspects of the historical process of Latin America's land management and the Amazon basin's past and current land use changes. Based on this review, the Amazon region shows two concrete challenges for resilience: (1) the natural system's fragmentation, as a consequence of land use limiting key ecological processes, and (2) the cultural and institutional fragmentation of land use projects designed and partially implemented in the region. In addition, the region presents challenges related to institutional design, the expansion and strengthening of real participation spaces, and the promotion of social learning. Finally, polycentric and adaptive governance is itself a major, urgent need for this region and its socialecological complexity.
\end{abstract}

Key Words: Amazon basin; land use planning; Latin America; resilience principles

\section{INTRODUCTION}

The aim of resilience thinking is to understand the mechanisms that guarantee a system's capacity to recover from external pressures, trauma, or disturbances, as well as changes in their internal dynamics (Holling 1973, Walker and Salt 2006). Predicting and foreseeing a substantial part of external disturbances and abrupt changes in the internal dynamics is difficult. Natural disasters, economic crises, and the spread of diseases are some illustrative examples (Bamberger and Kummins 2005, May et al. 2008, McGee 2011). Accordingly, resilience thinking proposes that although the ability to understand and anticipate these external traumas or abrupt changes increases, it is critical to comprehend and manage the mechanisms that sustain the capacity of a system to reorganize and recover (Zolli and Healy 2012, Ponce-Campos et al. 2013).

Resilient thinking presents an important evolution from its origins in the 1970s to the present, transforming from a constellation of ideas and hypotheses (sometimes tautological) focused on understanding the capacity of reorganization of systems subjected to shocks or external disturbances (Walker and Salt 2006, Carpenter and Brock 2008), toward a theoretical framework based on principles and centered on the simultaneous analysis of the adaptive and transformational capacity of complex systems (Biggs et al. 2015, Folke 2016). Currently, the focus of this approach not only involves the capacity for reorganization, but also the mechanisms that facilitate and promote transformational processes of configurations considered unfavorable or unsustainable, trying to overcome negative resilience mechanisms. Finally, it is important to highlight in recent years the progress in the analysis of multiple external pressures or drivers simultaneously impacting, an approach called systemic resilience (Scheffer et al. 2018, Rocha et al. 2018).

In this context, seven principles have been proposed, which are considered crucial for social-ecological systems to become resilient (Biggs et al. 2015, Simonsen et al. 2016): (1) preserve diversity and redundancy, (2) manage connectivity, (3) manage feedbacks and slow variables, (4) encourage complex adaptive systems thinking, (5) stimulate learning, (6) broaden participation, and (7) promote systems of polycentric governance. The relevant question to consider in the present assessment is this: how are the principles of resilient thinking incorporated into land use planning, and the provision of all associated goods and ecosystem services in the Amazon region? This question is crucial in territories where several and important soil transformations occur, such as the case of the Amazon region in Latin America.

This article emerged as a result of a workshop held at the South American Institute for Resilience and Sustainability Studies (SARAS) in March 2016. The workshop called "Seeking sustainable pathways for land use in South America" aimed to identify the gap in the analysis of global drivers and its impacts on land use decisions and ecosystem services. Researchers from different countries participated in the workshop presenting their experiences. One of the main conclusions of the workshop was that the resilience approach could be useful to find these "sustainable pathways." Based on this conclusion, we carried out different discussions and reviews of the literature to integrate all these concepts in the analysis of the case study selected: the Amazon biome. The present review briefly analyzes the main spatial and temporal patterns of the land use transformations and

${ }^{1}$ Universidad Jorge Tadeo Lozano, Programa de Doctorado en Ciencias Ambientales y Sostenibilidad, Bogota, Colombia, ${ }^{2}$ South American Institute for Resilience and Sustainability Studies, SARAS, Maldonado Uruguay, ${ }^{3}$ Departamento de Ecología y Gestión Ambiental, CURE, Universidad de la República, Maldonado-Uruguay, ${ }_{4}^{4}$ INTA, Centro Regional Buenos Aires Sur. Estación Experimental Agropecuaria Balcarce, Argentina, ${ }^{5}$ Grupo de Estudio de Agroecosistemas y Paisajes Rurales, Facultad de Ciencias Agrarias, Universidad Nacional de Mar del Plata, Balcarce, Argentina, ${ }^{6}$ Instituto de Investigaciones Ecológicas y Fisiológicas Vinculadas a la Agricultura (IFEVA-CONICET), Facultad de Agronomía, Universidad de Buenos Aires, Argentina, ${ }^{7}$ Conservation International Foundation - Colombia 
Fig. 1. The study area: Amazonia. Source: Modified from Neugarten et al. (2017).

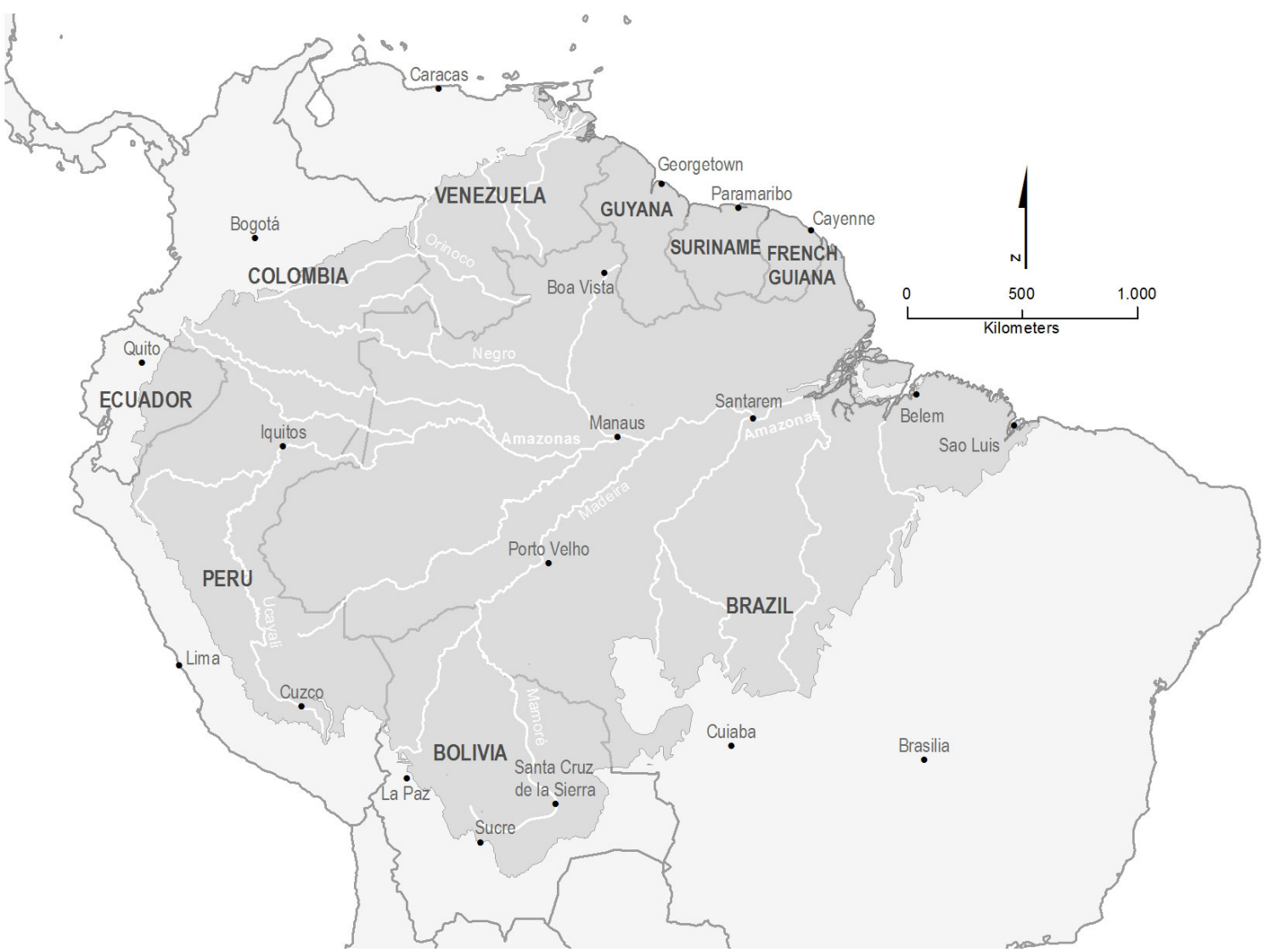

the governance system associated, the causal mechanisms and the challenges that land management poses in the Amazon region from the perspective of resilience thinking and the resilient management of social-ecological systems.

\section{METHODS}

\section{Research strategy}

The workshop organized by SARAS brought together specialists from different disciplinary domains, mainly from the area of economics, ecology, land planning, sociology, and political sciences, who are currently investigating in South America. In this sense, the team of authors of this review was formed to integrate the diversity of perspectives and generate a systemic analysis based on the theoretical framework of resilient thinking. The review includes the central aspects that determine adverse or unsustainable configurations on the Amazon region and identifies possible alternatives to explore and navigate. The review describes the current situation under the light of each resilience principle.

\section{The case study: the Amazon biome}

We have selected the Amazon basin as a study case because it is one of the continent's and biosphere's most important bioregions with regard to its biological, social, and cultural diversity and the ecosystem services it provides (Rice et al. 2018). Additionally, it was chosen because of the multiple pressures that currently and in the past have threatened the region's sustainability and the provision of crucial ecosystem services, adversely affecting human well-being. Forest loss may degrade vital ecosystem services such as carbon storage in biomass and soils, water balance and river flow regulation, regional climate regulation, and the control of infectious diseases like malaria and dengue fever (Gondim et al. 2017).

Amazonia is a region that covers areas from nine South American countries and contains the largest tropical rainforest in the world (Fig. 1). It comprises 53\% of the remaining tropical forests of the planet (Mittermeier et al. 2003). However, it is not only characterized by forests; several other unique ecosystems exist in the region, from vast grasslands that are seasonally flooded to the most protected mangrove areas on the planet. The Amazon forests contain almost one-third tropical carbon biomass stores (Saatchi et al. 2007), and nearly $10 \%$ of the world's endemic plant species (Mittermeier et al. 2003). The region is also home to the largest and most voluminous river in the world, the Amazon River, which is responsible for $20 \%$ of the freshwater that flows into the world's oceans (Marengo et al. 2013).

Approximately 34 million people live in Amazonia, which is 10\% of the population of South America, but the majority $(65 \%)$ lives in urban areas (ARA 2011). Roughly $45 \%$ of Amazonia's population is estimated to be living in poverty conditions. Nonetheless, the population is culturally diverse with a mixture of indigenous, African, and European influences. The indigenous 
culture predominates in the rural Amazon region, with nearly 375 indigenous communities and about 240 languages. The local people strongly depend on Amazon ecosystems for its abundance of goods and services; however, this basin provides several important ecosystem services to the rest of the world. Its forests, rivers, wetlands, and savannahs harbor countless numbers of species, provide freshwater flows that supply cities and the food industry, contain carbon sinks that mitigate global climate change, reduce the impacts of severe flooding, and provide sources of food, fuel, and raw materials for rural and traditional communities.

However, Amazonia is under threat. Deforestation has led to the loss of more than $13 \%$ of the region's forest cover since 1970 (RAISG 2015). Projections suggest that if the current pace of deforestation is not halted soon, climatic conditions will become drier and the system may become more open and drier, where fire risks are even higher and precipitation and humidity lower (Nobre 2014, Nobre et al. 2016). The most significant pressures to the Amazon ecosystems include roads, which are at the beginning of the deforestation process. There is a high correlation between paved roads and deforestation: it is estimated that $80 \%$ of the deforested area in the Brazilian Amazon is found within $30 \mathrm{~km}$ of paved roads (Barreto et al. 2006). Indeed, the presence of roads is an incentive to expand human settlements and intensify farming, logging, mining, and other human activities (RAISG 2013). In addition, land clearing for agricultural development may soon be overshadowed by forest diebacks associated with global climate change (Davidson et al. 2012, Jiménez-Muñoz et al. 2013).

Infrastructure development will bring economic opportunity to the residents of Amazonia, but the growth will lead to strong biodiversity losses. In addition to the economic pressures, there is also the indirect threat of atmospheric changes to biodiversity, mainly explained by possible regional decline in precipitation. Some simulations predict much of the eastern Amazon is under threat of slipping into a permanent "El Niño-like state," which can lead to a large-scale substitution of rainforest with savannahs (Cox et al. 2004).

Betts et al. (2004) show that $25 \%$ of the simulated decrease in rainfall is caused by positive feedbacks with forests disappearing, modifying the local climate, and inducing further dieback. Changes in temperature are more consistently predicted (Cramer et al. 2004) with models hinting at a tropical land temperature increase ranging from 2 to $8^{\circ} \mathrm{C}$ (typically $5^{\circ} \mathrm{C}$ ). However, their impacts on vegetation and biodiversity are less clear (Lewis et al. 2004). Higher temperatures may accelerate nutrient recycling and hasten growth but may also enhance evapotranspiration and respiration. Cowling et al. (2004) suggest that equatorial rainforests may not be far off from an upper temperature limit, at which point productivity and viability will begin to decline with the rising temperature. Changes in sunshine duration associated with cloudiness or aerosol haze may also have important consequences on biodiversity and productivity, but it is yet unclear whether sunshine duration is increasing or decreasing over Amazonian forests (Nemani et al. 2003). Agriculture, legal and illegal mining, oil and gas extraction, logging, and hydropower dams are among the most important deforestation pressures in the region. The main environmental impacts of deforestation include loss of biodiversity, reduction of water availability and regional rainfall, and $\mathrm{CO}_{2}$ emissions, which exacerbate global climate change (Fearnside 2005).

\section{RESULTS AND DISCUSSION}

\section{Land planning and management in Latin America: the historical trajectory}

Prior to European colonization, the original societies generated and applied different forms of space organization, many of which remain to this day. With the conquests of Spain and Portugal other forms of settlements were imposed. The territories under Spanish rule applied, with different adaptations for urbanization, the Laws of the Indies (of Renaissance origin), with primarily a checkerboard pattern. On the other hand, the cities founded by Portugal followed a more organic pattern (of Medieval origin), adaptive to the site (Durán-Roca 2006).

In the surroundings of the cities, in areas of exploitation or production of resources for export (precious minerals, coffee, cotton, and others), the extraction criterion was imposed, with territorial zoning according to the distance to the seaports. A large part of the infrastructure persisted over time based on a maintained model of export of raw materials. Large aboriginal communities were incorporated into the colonies, but always separating the power of the European people in the cities from the labor of the natives and slaves outside the city walls, in the periphery or countryside (Rama 1984). Urbanism was therefore an effort to organize space in terms of power: the territorial and social order was fundamental to strengthen the structure of domination and exploitation (Zambrano and Bernard 1993).

In regions, such the Pampas (east-central Argentina, Uruguay, and southwest of Brazil) the use of the territory was driven by other interests, where there were no attractive mining resources, demographic concentration was low, and with practices of seminomadism. In this case, the developed production was extensive cattle ranching in unregulated modes and without governmental controls. However, the city-country relationship was imposed equally: the first dominating and the second organized into large estates, controlled by the European owner or his descendants (Durán-Rocca 2009, de Dios 2013) with residence in the city (Carballal and Estellano 1996).

The 19th century brought independence in most of the Latin American territory. However, there were few immediate changes that were formalized in spatial planning. Prior to the emergence of land management policies in the 1980s and 1990s, diverse sectoral and multisectoral planning options were applied in Latin America (in the middle of the 20th century), such as regional planning, urban planning, economic and environmental planning, which gradually evolved toward land management (Akimoto 2009, Massiris 2012, 2017). Regional planning was based mostly on economic dimensions with a multisectoral vision. It was applied to certain areas with slow economic development but lacked a global perspective necessary for land management. Examples of such regional planning are the watershed plans in the 1940s of Peru, Mexico, Uruguay, and Colombia.

The environmental dimension of land management surfaced in 1970 , in association with the regulation of the use and exploitation of natural resources. Latin America's distinctiveness is that from 
the start, its land management has been connected to the "ecodevelopment" approach (United Nations Development Programme and Inter-American Development Bank 1991) to reinforce the concept that economic and social development must be integrated. This vision supports the document known as our own agenda on development and the environment (United Nations Development Programme and Inter-American Development Bank 1991:12), which was the product of a commission's work with representatives of various Latin American countries. The document was sponsored by the Inter-American Development Bank (IDB) and the United Nations Development Programme (UNDP), and had the support of organizations like the Economic Commission for Latin America and the Caribbean (ECLAC) and the Bariloche Foundation. Simultaneously, the actions in rural areas followed the standards of the Green Revolution. In this context, ideas of endogenous development and integrated rural development were employed (Akimoto 2009, Massiris 2012).

The fight against poverty reduction has characterized rural development in Latin America; however, it never became part of a national strategy for integrated development (Kay 2008). Its implementation was characterized rather by partial and sporadic measures, without sustainable policies to face the situation of social and economic exclusion of the rural poor. This is reflected in the instability of these measures depending on ideological, political, and economic cycles in the context of rising globalization and liberalization (Perz et al. 2010). Beyond definitions, the practices found constitute two types: one in which interdependence with land management is prevalent as a framework of sectoral policies and the other type is more organic and functionally integrated to strategic and/or environmental criteria.

In most cases, the development of land management plans and legal regulations began in the continent circa 1990, recognizing the transversal and intersectoral qualities of land management and in turn linking elements of environmental and urban-regional planning. From an analysis of the existing legislation on land management in Latin America, it can be understood as a planning process and tool of technical, political, and administrative nature, which is intended for the arrangement (in the long term) of an organized use and occupation of the land in accordance with the land's possibilities and limitations, the population's expectations and aspirations, and the development goals. Such land management is stipulated in plans that express the long-term land use and management model society deems desirable as well as the strategies needed to make it a reality (Massiris 2012).

Scarce social participation and weak institutions are other features that typify the definitions and laws of land management and spatial planning in Latin America, although it occurs in differing degrees (Hernández 2010). On the continental scale, the absence of a culture of participatory planning and limited knowledge of consensus and conflict resolution methodologies predominate (Arias and Vargas 2010, Needham and Buitelaar 2012, Caser and Cebola 2017). The absence or weakness of institutional organizations and the cultural traditions that endorse coordinated, cooperative, interdisciplinary, flexible, and open work, are among the most important obstacles for implementing systematic approaches of land management. Therefore, the absence of a vision of the future, which implies final consensual and long-term goals is probably a consequence of the lack of strong institutions with participatory approaches on environmental planning (Bravo 2007, Wong-González 2012, Levitsky and Murillo 2013).

\section{Key attributes to emphasize land management in historical Latin} America

The historical process of land management in Latin America shows a prevalence of local analyses and actions, based on the management of one or a few natural resources without considering the interactions between them, the sustainability in the mid to long term, or a suitable combination of temporal and spatial scales. Fragmentation in the analysis, decision making, and planning were the result of reductionist approaches in which social and natural systems were generally analyzed and managed independently (Ramírez et al. 2015, Angarita-Báez et al. 2017, García-Márquez et al. 2017). The natural resource management paradigm (steady-state resource management; Chapin et al. 2009) dominates the Latin American scene, while ecosystem management is gradually being incorporated into it. The ecosystem services approach emerged as an ideal tool to contribute to planning processes because it facilitates the integration of these services and allows an understanding of the relationships and dependencies between nature's components and societal well-being. The inclusion of ecosystem services rationale in public policies and land use planning has been strongly suggested by the international scientific community in the last decade (Maes et al. 2012) and more recently by Latin American scientists (Laterra and Nahuelhual 2014, Weyland et al. 2019). In this context, the greatest challenge is promoting and designing new spatial arrangements for land use that will guarantee the provision of assorted ecosystem services and generate land use plans that increase resilience and adaptability to known and unknown pressures (Driscoll and Galland 2014, García-Márquez et al. 2017, Stimson 2017).

\section{The current situation of the Amazon region and the seven principles of resilient thinking}

\section{Principle 1: Preserve diversity and redundancy}

Key message: Biodiversity and redundancy loss in the Amazon biome severely limits the long-term provision of fundamental ecosystem services in diverse spatial scales (local, regional, and global). Such loss erodes the system's ability to be resilient to external pressures and changes in its internal dynamics.

This principle states that systems with many components, such as species, actors, or sources of knowledge, are generally more resilient than systems with few components. This leads to redundancy, which provides "insurance" by allowing some components to compensate for the loss or failure of others. The diversity of natural, social, and economic components of a socialecological system presents multiple options in the face of change. Redundancy in the components allows some of them to balance for the loss or failure of others. Furthermore, redundancy is even more robust when these components react in different ways to changes and disturbances (Biggs et al. 2015, Simonsen et al. 2016).

For the Amazon region, recent assessments of the ecological impacts of land use practices (Foley et al. 2005, 2007) have focused on the need to balance the trade-offs that result from human 
Fig. 2. Current Amazonian situation, threats, and management forms. Source: Modified from Neugarten et al. (2017).

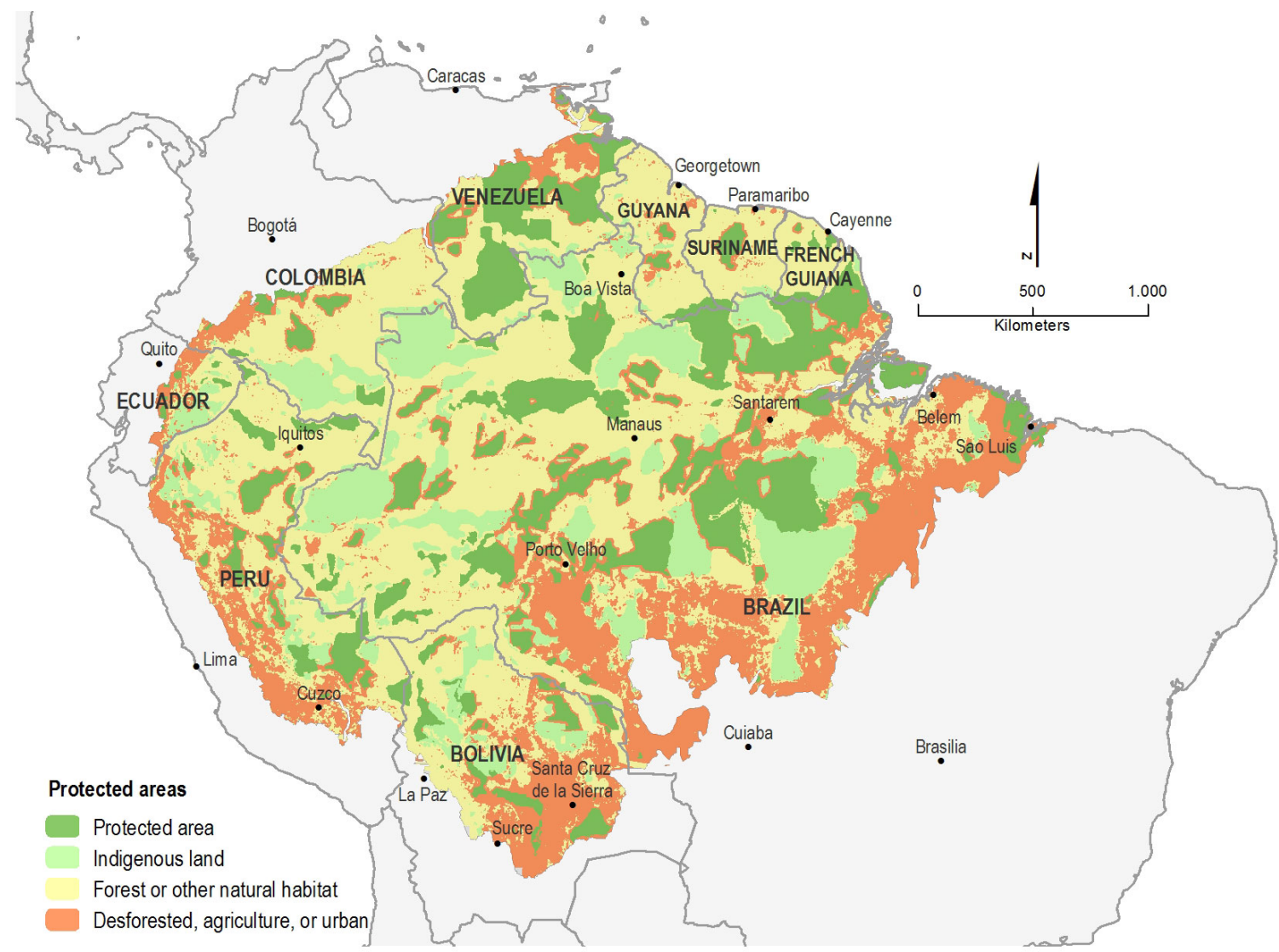

activities. In this context, deforestation is recognized as providing important benefits for society because it increases economic opportunities and the availability of many ecosystem goods at least in the short term (Fig. 2). However, the loss of rainforests may also cause biodiversity losses and degradation of many critical ecosystem services such as carbon storage in forests and soils, regulation of the water balance and river flow, modulation of atmospheric circulation and regional climate, and the amelioration of infectious diseases. Projections of deforestation suggest that if the current rate of deforestation is not halted soon, climatic conditions will become drier resulting in a higher risk of fire and lower precipitation and humidity levels (Nobre 2014, Recio 2017). Thus, deforestation trade-offs involve the recognition of short-term advantages by exploiting certain provision ecosystem services (wood, crops, etc.), while potentially degrading habitats, biodiversity, and ecological functioning in the long term (degrading mainly regulating and supporting services).

The priority areas for biodiversity conservation in the Amazon region derived from national and regional assessments (Fig. 3) and comprise more than 566 million hectares, which is about $70 \%$ of the total study area. The priority areas category referred to as "Very High" is the most significant one with almost 270 million hectares, while the "High" and "Medium" priority areas comprise 128 and 161 million hectares, respectively. Protected areas and indigenous lands overlap with $34 \%$ and $25 \%$ of the total priority area, respectively. Because of the overlap between these two categories, around $50 \%$ in total of all biodiversity priority areas have some type of formal land use designation. Given the intensification of threats to Amazonia, a question arises as to whether current policies are adequate for successful conservation across the entire region. Of concern are conservation policies based on protected areas (PAs), which to date have functioned as repositories of biodiversity and undisturbed ecosystems and carbon (Soares-Filho et al. 2006, 2010). Unfortunately, projections of future hydro-climatological conditions suggest that external climate forcing will significantly disturb several PAs in Amazonian countries (Salazar et al. 2007, Lewis et al. 2011, Zemp et al. 2017, Simmons et al. 2018).

Losses of habitat and biodiversity are promoted by large scale infrastructure investment (Simmons et al. 2018). For example, the building of roads and dams under Brazil's military regime (1964 1985) opened the region to colonization and development, promoting deforestation (Walker et al. 2009). The current infrastructure plan represents a strong increase in investments and land clearing, involving not just Brazil but all South America. It seeks to industrialize the economies of the Amazonian nations (Brazil, Bolivia, Colombia, Ecuador, French Guiana, Guyana, Peru, Suriname, and Venezuela) and to dramatically expand the region's engagement in global commodity markets, during a time when climate change will intensify across the region (Laurance 2007). 
Fig. 3. Priority areas for biodiversity conservation, based on national and regional assessments. Source: Modified from Neugarten et al. (2017).

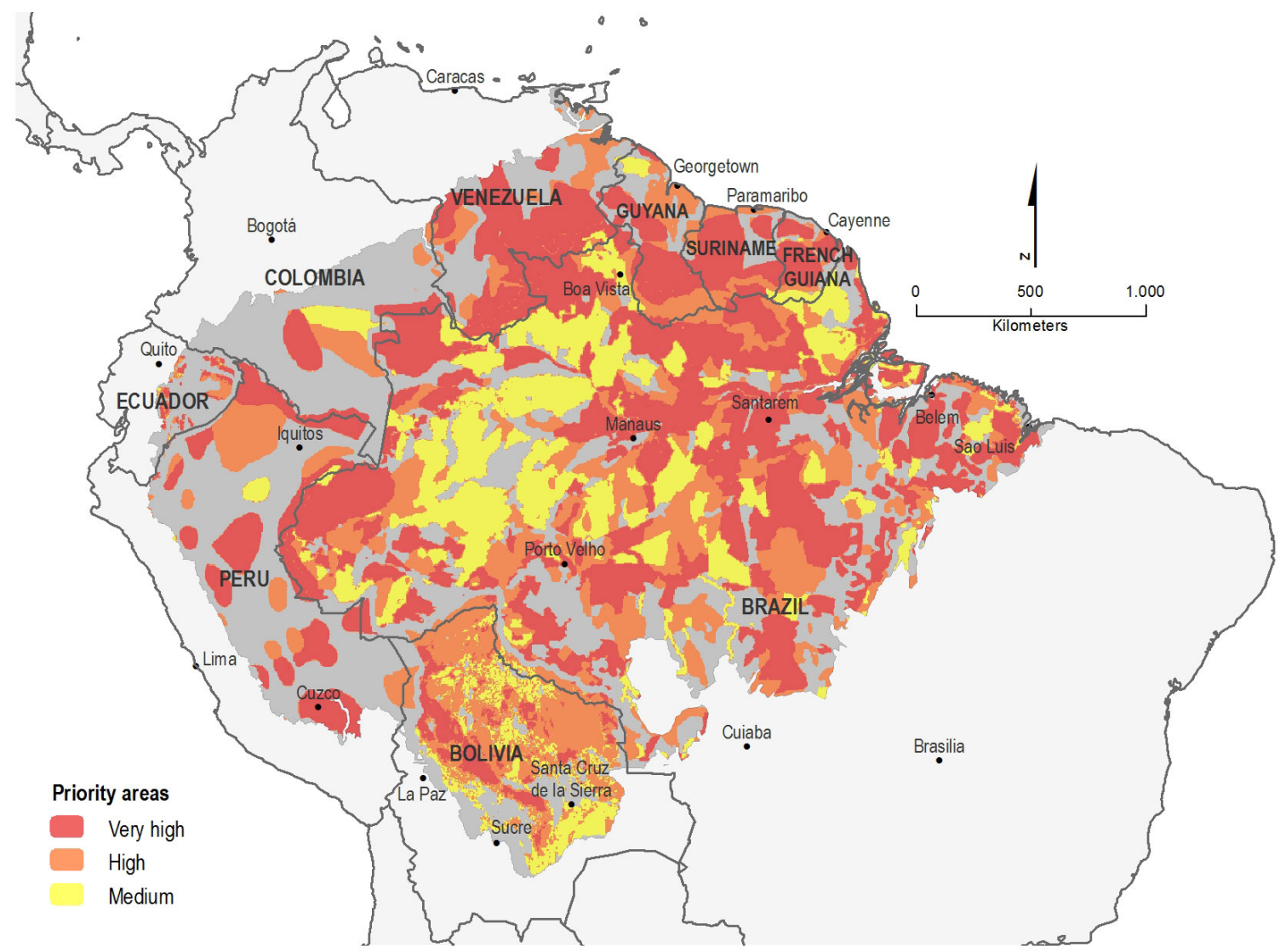

The IIRSA (Iniciativa para la Integración de la Infraestructura Regional Suramericana, in Spanish) project objective is the transformation of Amazonia into a transportation hub, connecting the Atlantic and Pacific Oceans, as well as the Amazonian region with the rest of South America (Simmons et al. 2018, Walker and Simmons 2018). This will be accomplished by the implementation of a logistical system of navigable waterways $(20,000 \mathrm{~km})$, a system of ports, a transcontinental railway with over $15,000 \mathrm{~km}$ of new tracks, and improvements to $\sim 2$ million $\mathrm{km}$ of roads (COSIPLAN, http://www.iirsa.org/ infographic\#ama), which implies strong habitat degradation in central Amazonia but also in its coastal ecosystems. The overall infrastructure program also includes hydropower projects undertaken by the individual South American nations sharing the basin. So far, 177 plants have been built (or are under construction), 241 planned, and 220 inventoried (International Rivers [date unknown]), with large areas being flooded and extensive habitat loss. The build-up in hydropower will make the region attractive to electricity-intensive industries across a wide range of goods including steel casting, aluminum siding, basic chemicals, synthetic fibers, glass products, consumer electronics, and automobiles (Michielsen 2013). In addition to federal projects, state and local governments are participating with their own complementary infrastructure initiatives. Biodiversity losses are expected to be considerable if all these activities take place without strong environmental planning.
Another central aspect is the broad but fragile cultural diversity of the Amazon region. Indigenous peoples living in small-scale societies have developed a complex body of ecological knowledge for interacting with their surrounding environment (Gray et al. 2008). They often control highly biodiverse regions and may manage landscapes to maintain a large amount of forest cover, sometimes even enhancing biodiversity levels (Posey and Balick 2006). Nevertheless, as indigenous peoples embrace new cultural values and attitudes influenced by Western societies, they also change their worldview, social organization, behaviors, traditional ecological knowledge, and attitudes toward nature, all of which may affect the composition and configuration of their surrounding landscape (Rudel et al. 2002). The findings of different studies indicate variation across borders, which can be partly explained by the paved roads and some of the mediating factors. Moreover, they show considerable net migration and turnover, both indicative of erosion in the collective memory and lack of demographic resilience to externally induced change (Perz et al. 2010, Aukema et al. 2017). These trends generate biodiversity loss and redundancy loss, although the evidence for this last point is not properly established.

Principle 2: Manage connectivity

Key message: Given the intensification of threats to Amazonia, there are two predominant challenges in the management of the Amazon region's connectivity: (1) the natural system's 
Fig. 4. Essential natural capital: the areas of the greatest importance regarding endemism evaluated. Source: Modified from Neugarten et al. (2017).

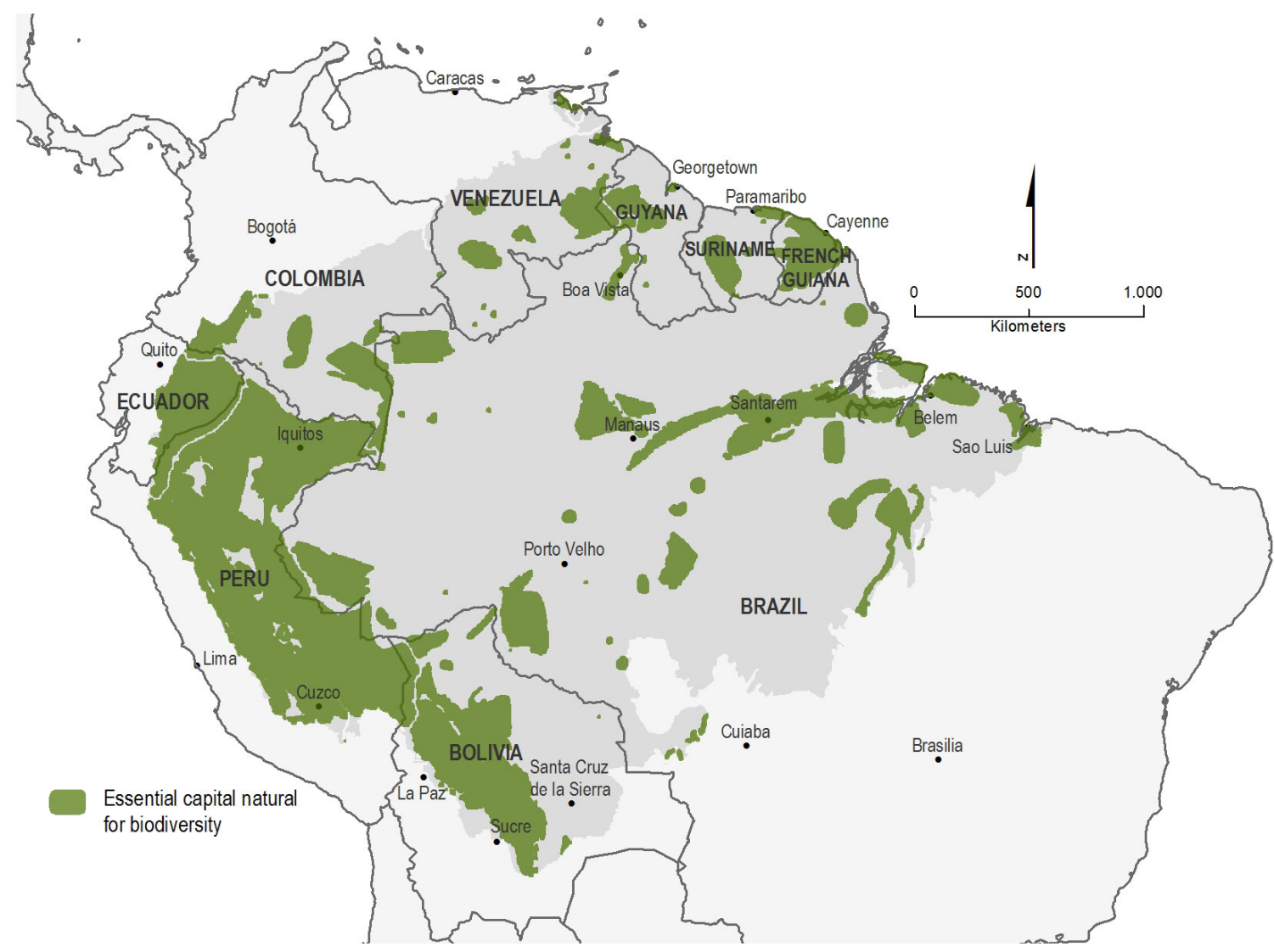

fragmentation, product of land use limiting key ecological processes, and (2) the cultural and institutional fragmentation, by land use projects designed and partially implemented in the region.

Connectivity loss can affect both positive and negatively ecosystem functioning, but negative effects predominate in the Amazonian region. Well-connected systems can recover from disturbances more quickly, but overly connected systems may lead to rapid spread of disturbances. Perhaps the most positive effect of landscape connectivity is that it can contribute to the maintenance of biodiversity (Brudvig et al. 2009, Tambosi et al. 2014).

Tropical deforestation and forest fragmentation resulting from land use changes are leading sources of concern in the research community, because of their consequences for both climate change and the decline in global biodiversity (Tapia-Armijos et al. 2015, Vedovato et al. 2016). Other effects include species extinctions, loss of ecosystem services, and increased habitat vulnerability, with long-term changes in landscape configuration that lead to a fragmentation process (Skole and Tucker 1993, Tapia-Armijos et al. 2015). One consequence is the appearance of small, noncontiguous fragments, in different years and with varying sizes and levels of isolation, separated by a matrix of human-transformed land cover (Broadbent et al. 2008, Haddad et al. 2015). A new ecological and hydrological cycle, therefore, begins in each new fragment. All these land use transformations affect forest-dependent populations, forcing them to change their livelihoods and traditions (Albert et al. 2011, Cabral and Costa 2017).

In a scenario of biological and cultural complexity, connectivity is an essential element both in biophysical terms, seeing as priorities have already been defined (Fig. 4), and from the institutional, social, and cultural points of view. There are two predominant challenges in the Amazon region for connectivity management: (1) the natural system's fragmentation, promoted by land use changes and limiting key ecological processes and ecosystem services provision, and (2) the cultural and institutional fragmentation of projects designed and partially implemented in the region. In the case of the first challenge, the areas most vulnerable to deforestation were defined by the Conservation International Foundation 2016 (Fig. 5). Amalgamating conservation efforts and coordinating actions seems to be a strong priority in the Amazonian region for managing connectivity, not well achieved by the weak and changing institutions in the region. More than a dozen unconnected programs, policies, instruments, and strategies are addressing these areas at the regional and local levels, which is contingent on international cooperation offers or the current regional and national government's priorities. Most of these programs seek limited local goals, not articulated among 
Fig. 5. Vulnerability to deforestation based on recent deforestation projections from 2010 to 2014. Values range from $0 \%$ per year (low) to $20 \%$ per year (high) per $1 \mathrm{~km}$ square pixel. Source: Modified from Neugarten et al. (2017).

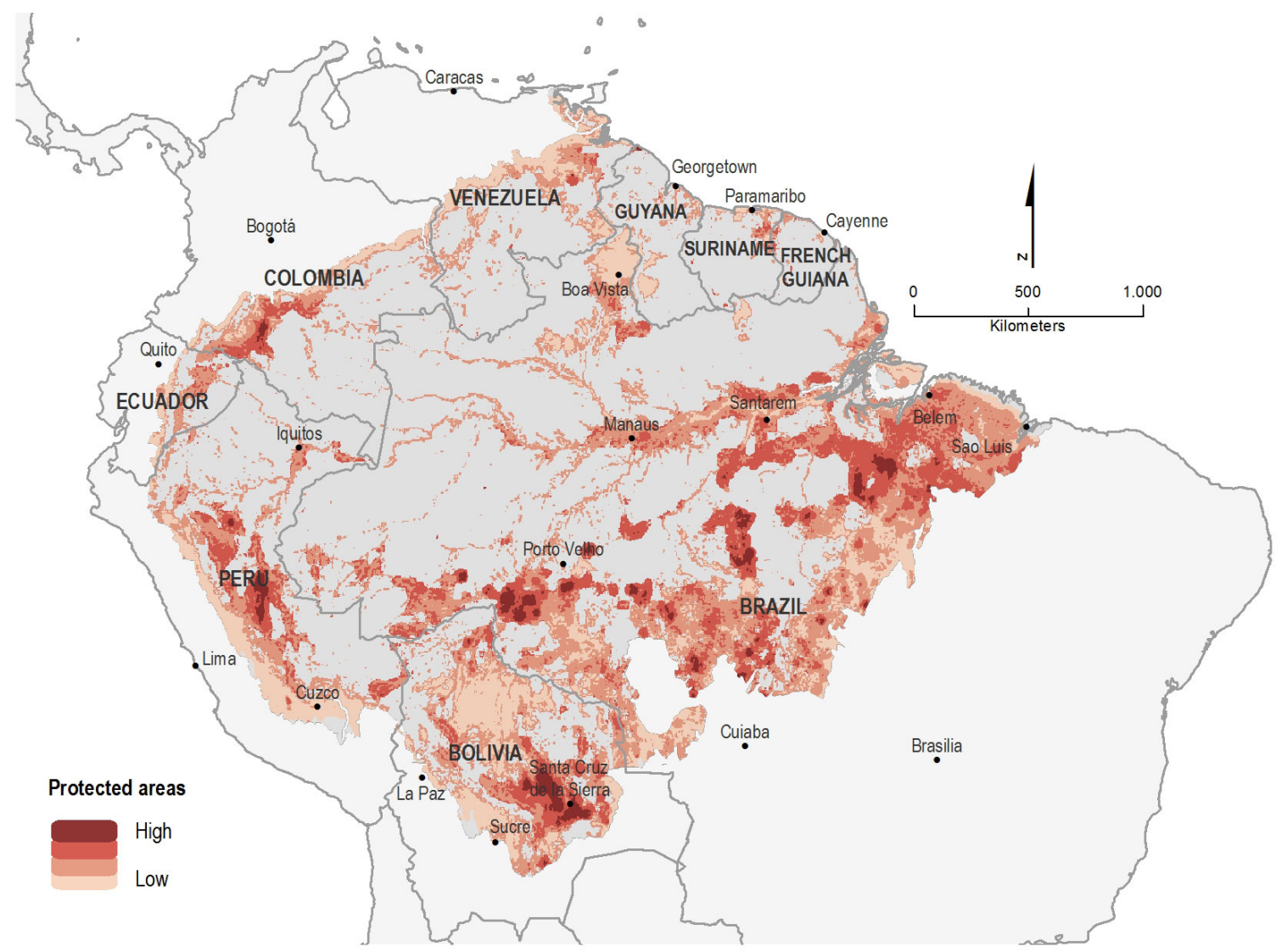

other projects, wasting the opportunity of achieving long-term coordinated goals.

To overcome the first challenge, only a few regional proposals address the fragmentation problem of the natural ecosystems and protected areas networks in the Amazon region. In this way, it is necessary to highlight the proposal to adapting all Amazonia's PAs into a system of refugee (SR; Hannah 2008, Simmons et al. 2016). Conceptually, the SR integrates the identification of connected thermal corridors (McGuire et al. 2016) and "cool" environments that can serve as a refuge in the face of climate change (Shoo et al. 2011). Obviously, this is only an academic proposal that would imply an important political and institutional organization of the Amazonian countries to put it into practice. The SR as conceptualized represents a policy instrument dedicated to the conservation of Amazonian forests and ecosystem services across all the Amazonian countries. This leaves an important question about human populations residing in indigenous reserves, and other traditional communities.

In terms of the second challenge, the Amazonian communities are culturally diverse and spatially scattered and isolated (Fig. 6). The latter makes coordination and connectivity difficult between them and the institutions that represent them. Traditional management instruments such as watershed management plans or municipal land-use plans do not apply to a socio-cultural context like that of the Amazon region. Erazo (2010), Perz et al. (2010), and Magnuszewski et al. (2015) corroborate the existence of these challenges through empirical evidence. Additionally, they reveal the efforts the Amazon indigenous leaders made over the last four decades to establish their local organizations, particularly when it came to promote collective commitment to marketoriented activities. The Conservation Agreements and other complementary mechanisms for Amazon conservation (Rosselli et al. 2014) represent concrete examples for encouraging the exchange, coordination, and connectivity consideration, thus managing it through cross-cutting issues of the Amazon region. Initiatives such as Amazonia Vision 2020 (MADS 2015) seek to accomplish the recognition of socio-cultural differences at an intergovernmental level, to foster regional connectivity and go beyond the construction of roads and the scattered population dynamics. The biggest challenge is finding suitable socioeconomic and cultural connectivity; without it, the susceptibility to loss of biodiversity and ecosystem services in the Amazon region will progressively rise.

Principle 3: Manage slow variables and feedbacks

Key message: The emerging evidence shows that the Amazon biome is undergoing a major biophysical transition, indicating the need for a better understanding of the interactions between 
Fig. 6. Settlement patterns in the Amazon. Source: Modified from Neugarten et al. (2017).

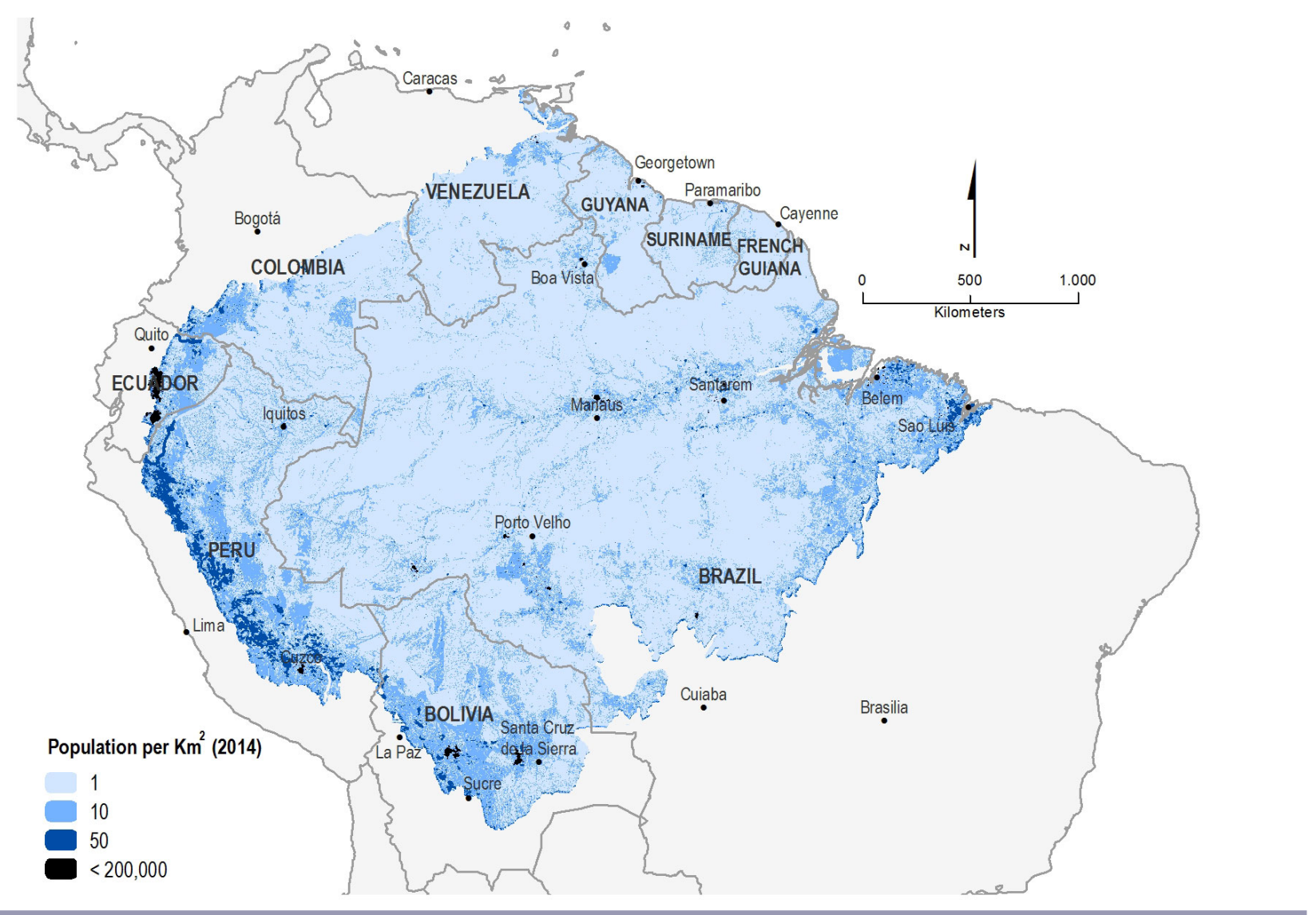

land cover, carbon reservoirs, water resources, habitat conservation, human health, and economic development in future scenarios of climate change and land use. A better understanding of vulnerability and resilience of the Amazonian ecosystems when confronted with external pressures or abrupt changes in their internal dynamics is required to maintain the biotic integrity of the biome and the ecosystem services it offers to local, regional, and global communities.

There are numerous possibilities for interaction between system's components, with these interactions determining the different configurations, which in turn provide different ecosystem services. The management of slow variables and feedbacks is key for preserving systems in desired configurations and expected service provision. If these systems shift to a different configuration, their reversal may be very difficult to achieve. Davidson et al. (2012) provide a framework to appreciate the connections between natural variability, factors driving change, and the reactions and responses in the Amazon basin. Despite the uncertainty in the whole basin's carbon balance, the evidence is emerging of a directional change in its role from sink to source. Although the duration of the dry season is lengthening, river discharge is increasing during the wet season. The forest is resilient to significant natural climatic variation, but the global and regional climatic disparities interact with land use changes, deforestation, and fire in complex ways, which in general result in forest ecosystems that are increasingly vulnerable to degradation.
Undeniably, it is fundamental to understand the links between system variables and attributes with different temporal dynamics as well as their role in maintaining the current configuration or possible desired and undesired transformations (Silvestrini et al. 2011).

The resilience and stability of the Amazon forests are key for the biosphere long-term functioning. Recent studies ascertain the considerable resilience of Amazon forests in the face of moderate annual droughts. However, they also show that interactions between deforestation, fires, and drought can potentially result in carbon storage loss and changes in regional precipitation patterns and river discharge (Davidson et al. 2012). Although the impacts of land use and drought across the basin cannot yet exceed the scale of the natural variability of the hydrologic and biogeochemical cycles, there are some signs of a shift toward a prevalence of anthropogenic disturbances. Understanding the interactions among these factors is key for managing slow variables that change long-term system's configuration. For thousands of years, human beings have been a part of the Amazon's vast system of forests and rivers, and yet, during the last decades, the expansion and intensification of agriculture, deforestation, and urban settlements has been unprecedented (Davidson et al. 2012). Between 1960 and 2010, the Brazilian Amazon region's population grew from 6 to 25 million people, while the forest cover diminished to approximately $80 \%$ of its original area (INPE 2011). International and national demands 
for meat progressively incite changes in land use. While cleared, the land is predominantly used for livestock farming; a faster and better conversion to agricultural land use is becoming increasingly important, mainly for soybean and palm oil exports. Ever since early 2000, this has defined a trend of forest loss throughout the Amazon region (Foley et al. 2007). Recent efforts to curb deforestation have led to a considerable decline in its occurrence throughout Amazonia, decreasing from almost $28,000 \mathrm{~km}^{2}$ in 2004 to less than $7000 \mathrm{~km}^{2}$ in 2011 . However, the progress made is still fragile. In fact, this trend is being reversed by several and simultaneous political and economic processes in Colombia, Venezuela, and Brazil (Reardon 2018). Nevertheless, the impacts of Amazon forest losses on long-term global functioning seem to be critical.

Selective logging has also been identified as a major threat to the Amazonian long-term existence. Although selective logging does not entail an immediate change in land use and forest area losses, it often does lead to deforestation. Annual records of the Amazon basin from 1999 to 2003 indicate that the area targeted for this practice was similar in size to that of the deforested area. The registered areas are accessible by roads, and it is highly probable that following the initial disturbance, they are cleared within a few years. Moreover, the areas that are not cleared are prone to fire. Alternatively, reduced impact logging has been shown to be economically viable, while only causing slight and temporary impacts on carbon storage and water exchange (Miller et al. 2011). Managing selective and reduced impact logging adequately in the region may have important feedbacks to biodiversity conservation and the overall functioning of the Amazonian rainforests.

The establishment of protected areas in the Amazon basin is an important, albeit insufficient component to warrant large areas of forests that may maintain the biome in the long-term. The current trends in the agricultural expansion will eliminate $40 \%$ of the Amazon forests by 2050, including at least two-thirds of the forest cover in 6 main watersheds and 12 Eco regions. A quarter of the 382 recorded mammal species will lose over $40 \%$ of the forest they inhabit. Although an amplified and reinforced network of protected areas may avoid a third of the projected forest loss, conservation of private lands is also crucial. Critical factors in an integrated conservation strategy include the increases of market pressures for adequate land management and discouragement of logging on land unsuitable for agriculture. Coordinated management and planning of protected areas in the long term seems to be a key slow variable that should be approached to warrant the forest conservation.

Principle 4: Foster complex adaptive systems thinking

Key message: A wide range and number of institutions responsible for planning and managing the Amazon region (ministries, directorates, municipalities, programs, etc.) are in different areas and levels, they do not interact with each other, and when they do, they have a scarce systemic vision of the decision-making process.

A complex adaptive system (CAS) approach means accepting that within a social-ecological system, several connections are occurring at the same time on different levels. It also means accepting unpredictability and uncertainty and acknowledging a multitude of perspectives. Holling et al. (2000) characterize two streams of science relevant to understanding conservation and resource management problems. The first stream referred to as a science of the parts, is exemplified by the concept of maximum sustainable yield from the stock/recruitment models (see the paradigm of natural resource management in Chapin et al. 2009). This science of the parts generates unambiguous data although at the cost of being fragmentary. For Lu (2010), this science appears to have contributed to a resource management crisis because it seems unable to define sustainable results or explain the collapse of resources. The other stream is described as a science of the integration of parts, in which the coupled human and natural system is recognized as highly complex, unpredictable, nonlinear, scalar, evolutionary, and distinguished by feedbacks and uncertainty (Holling et al. 2000, Chapin et al. 2009). Nice examples of complex adaptive systems approach have been described by $\mathrm{Lu}$ (2010) with the Huaorani communities of Ecuadorian Amazon and Josse et al. (2013) on the Peruvian Amazon. They illustrate the possibility to learn, stimulate, or at least respect communities' resilient behaviors and actions for resource management, particularly because the communities have settled in these territories for long periods and have maintained a proper adaptation and resilience capacity.

In addition, for applying a CAS approach it is also necessary to understand the sectoral and institutional fragmentation, which manifests in decontextualized analyzes of an array of institutions (ministries, directorates, municipalities, programs, etc.) that are situated on different levels without interactions between them. These institutions usually are absent of a systemic vision about the decision-making process, and the integration of the cooperation strategies, visions, or programs that have been developed or are currently being developed in the Amazon region. To overcome these challenges, the following questions arise: (1) Do these programs identify the same vision or a perspective that acknowledges the diversity and heterogeneity of this vast and important region? (2) Are different knowledge types beyond the technical one being considered in the development of these visions for the land use planning? And if so, how is it being carried out? (3) Do current land management models and tools capture the Amazon region diversity, and are they compatible with its context? It is evident that these emerging questions represent a very large institutional and social challenge. It is important to consider in the analysis of these questions the role of secondary and tertiary education systems in Latin America, where the predominance of fragmentation and reductionism continues, with a weak formation in systems theory in many disciplinary domains.

\section{Principle 5: Encourage learning}

Key message: There can be no learning without lessons learned, which is why it is fundamental to evaluate the impact and results of management policies that traditionally have been applied to the Amazon region by the respective Amazonian countries' governments as well as by nongovernmental organizations (NGOs) and international multilateral cooperation institutions. Without an evaluation, there is no way to advance toward a learning process that involves other types of knowledge within a resilience thinking and complexity framework.

Social-ecological systems are always in development so there is a constant need to revise existing knowledge and stimulate learning. 
More collaborative processes can also help. Learning and experimentation through adaptive and collaborative management is a key mechanism to develop resilience. Land use planning and management programs and strategies consist of known and unknown certainties and uncertainties. Nevertheless, uncertainty must not restrain the decision-making processes; rather it is an intrinsic characteristic that we must learn to work with. Learning by doing must happen while evading the adoption of measures, strategies, or policies that restrict future options.

Although there is a massive accumulation of information regarding the environmental, socioeconomic, and socio-cultural dimensions of the Amazon region, it is evident that this knowledge is fragmented, limited, and relegated to scattered sources difficult to access for use in decision making. Also, it presents two key characteristics: epistemic uncertainty, derived from an imperfect understanding of a system, and ontological uncertainty, related to an inherent variability and unpredictability in the system itself (Brugnach et al. 2008, Walker et al. 2013). Under these premises, the perfect understanding of a system is not possible. Therefore, managing the uncertainty and the recognition of possible transitions and outcomes in the Amazon region becomes a fundamental condition to learn about change and its potential consequences in academic, political, and traditional levels.

Contributions like that of Phalan et al. (2013), have elucidated the potential consequences the expansion of crops such as soybean and palm oil can have on the Amazon's resilience and sustainability, some of which are highly incompatible with the region's diversity. Marquardt et al. (2013) demonstrated how several small landowners in Amazonia employ shifting cultivation systems such as slash-and-burn, in which the forest is the primary source of natural soil enrichment. However, governmental regulations have diminished opportunities to claim natural forests for agriculture. The results of this indicate that farmers establish improved crop rotation using contextual ecological knowledge and diverse techniques to introduce a great diversity of tree species. These practices are also utilized to restore degraded lands to agricultural production.

The conservation production paradigm in the Amazonian forest calls for a better understanding and learning of integrated production systems. Therefore, the tasks of sustaining productivity on agricultural land and reforestation of degraded areas are gradually becoming more urgent in the Amazon region. Thus, the agricultural practices that incorporate reforestation and forest management are highly relevant. Because cultivation systems are the basis of the livelihoods of most Amazonian small farmers, their good agricultural practices and their traditional knowledge are important for the sustainability of the Amazon's small-scale agricultural systems. Following this argument and with a more transdisciplinary view, Jakovac et al. (2015) explored how the intensification in land use affects forest resilience. This becomes a key element to elucidate the underlying mechanisms of regeneration and planning processes aimed at more sustainable land use systems for the Amazon region. In summary, the researchers demonstrated that farming with traditional practices, based on the traditional ecological knowledge of the Amazon's indigenous people and peasant settlers, enhances the system's resilience as these practices generate more ecosystem services.
Jakovac et al. (2015:67) concluded that in the Amazon, "the adaptation of management practices is needed to guarantee the resilience of cultivation systems."

The integration of local and indigenous knowledge in the scientific learning process will surely benefit the overall understanding of ecosystem functioning and structure. New techniques have emerged that utilize local (or traditional) ecological knowledge to monitor species distributions and population trends over time. These, alongside the use of geospatial technologies, can adequately defeat the constraints of assessing large natural areas such as the Amazonian region (Ostrom et al. 1999, Kerr and Ostrovsky 2003). The coupling of the nonindigenous researchers and stakeholders' knowledge with that of the indigenous communities may inform sustainable management practices that are respectful of indigenous perspectives and intellectual property rights. Nevertheless, there are ontological, epistemological, political, and financial obstacles and limitations that must be addressed in transdisciplinary research projects that link the academic, technical, and indigenous knowledge systems for environmental and economic management (Athayde et al. 2016, Angarita-Baéz et al. 2017). Both in the indigenous and scientific perspectives, diversity is a key aspect to maintain exotic and native species in balance, thus avoiding major competition and their extinction.

\section{Principle 6: Broaden participation}

Key message: By analyzing the principles of resilience in the Amazon region, it is evident that tension between conservation and development (in the traditional-neoclassical sense) is where active, informed, and coherent participation from all the Amazon's diverse stakeholders must emerge.

There are a range of advantages to broad and well-functioning participation in land use planning projects. Informed and wellfunctioning groups have the potential to build trust and a shared understanding, both fundamental ingredients for collective action. The active participation of all stakeholders allows them to develop trust, expedites understanding, and incorporates different perspectives, facilitating processes of accountability and legitimation. These aspects are not included in traditional technical and scientific methods. The major challenge for a concrete participation scenario is the construction of communication channels or structures that last and are representative of the diversity present in a region of great socialecological complexity as the Amazon. In this sense, land use planning should be a process in which the interested parties work together to establish common guidelines and to understand their future options and land uses. Furthermore, it is a combination of different approaches and disciplinary or interdisciplinary perspectives that gather a diversity of stakeholders to identify their attitudes, aspirations, needs, impacts, tensions, and conflicts. However, this principle poses considerable challenges relating to institutional coordination, the expansion and strengthening of spaces for true participation, and the establishment of flexible governance systems oriented to learning (adaptive governance) (Boyd and Folke 2012).

From a resilient thinking approach the integration of analytical approaches and participatory techniques are key to plan the sustainable use of land resources and landscape changes. Nijnik et al. (2011) showed for two cases from South America and Europe 
that increased stakeholder participation in decision making has produced a higher level of satisfaction among the participants and a greater understanding of issues relating to rural land use and landscape change. Comparisons between processes in both continents highlight similarities and differences that provide a basis for discussing locally distinctive guidelines and good practices in rural areas. This works suggests that the way in which researchers conceptualize land use systems and represent them in a landscape, provides a basis for decision making, particularly when they have significant political and economic implications. The integration of ethnographic and participatory assessments in the case of the Marajo Island's agroforestry (Brazilian Amazon) has conveyed greater details when analyzing land use patterns that ultimately help to represent more accurately the stakeholders and their landscape management.

According to Gondim et al. (2017), the increase of social participation in the planning and management of Amazon conservation areas can significantly mitigate conflicts in these territorial units, giving enough basis for the construction of a project of conservation and preservation of the environment of endogenous nature. The difficulties in safeguarding the environmental rights of Amazon communities generate an increase in inequality, changes in lifestyles, and the expansion of disputes and social conflicts. To counteract all these negative elements, the actions must be based on environmental ethics in order to generate a message against the destabilizing system and allow the resumption of awareness of the role of man in the environmental system.

\section{Principle 7: Promote polycentric governance}

Key message: A hierarchical, centralist, and vertical view of the modern state predominates in Amazonian management, which is incapable of meeting the needs for flexibility, uncertainty, experimentation, and constant adaptation required for the resolution of contemporary problems.

Polycentrism refers to governance systems in which multiple organizations and stakeholders interact to create and enforce rules within a frame of policies or a specific topic. It is considered one of the best ways to accomplish collective action against disturbances and change. Collaborations between institutions and stakeholders improve connectivity and learning across multiple scales and cultures. Moreover, well-connected governance structures may deal with changes and disruptions rapidly given that the appropriate people handle them at the appropriate time. The basic element for the multilevel coordination that polycentric governance demands is information that is widely accessible as well as clear. Mann et al. (2012) clarifies that even though one option may be theoretically better for a common good, i.e., a proposal for an economic instrument like payment for ecosystem services, it is only possible to make the right decision through the adequate coordination of different decision levels. As opposed to the wrong decision, this would only benefit a certain group that is not representative of the region and its members. A response to this is the development of experimentation capabilities in the face of unpredictable and changing problems and learning to be tolerant of certainty and uncertainty. However, a precondition is the need for changes in the organizational functioning, e.g. normative, structural, and functional framework, and new skills and competencies to advance to a real decentralization process.
Several findings point to an important interplay of decentralization, governance, monitoring, and policy making requiring the involvement of all important actors to reach, for example, a zero-deforestation goal or reduce forest degradation in the Amazon. The combination of law enforcement, close monitoring, and the soy and beef moratoria have contributed to the decline in deforestation rates in the Brazilian Amazon (Nepstad et al. 2004, 2008, 2014, Godar et al. 2014). In fact, land use change and shifts in land uses after deforestation show spatial heterogeneity in the Amazon region, suggesting the need of spatially appropriate and decentralized policies (Müller-Hansen et al. 2017).

The Amazon region has been undergoing occupation and integration processes for more than a century, which led to serious social and environmental repercussions because its specificities were not taken into account (Pasquis 2005). Historically, different governments and their respective political programs (with a centralist vision) have considered the Amazon region as a homogeneous space, accelerating the exploitation of their natural resources. This resulted in the formation of a deforestation arc that moves toward the center of the region in a sequence of extractive and productive activities that result in high deforestation rates and large degraded areas (Pasquis 2006a,b). It is important to remember that the theory of polycentric governance tells us that in the use of common resources of a locality, the best management of the territory is that which establishes interscalar or transscalar relations between different institutional, formal, and nonformal levels (Berkes 2002). The relationships that allow establishing links between local and external institutions (regional and national, for example), strengthen regulatory mechanisms and give flexibility and agility to local institutions, allowing better use and improvement of these. The construction of this institutionally of different levels implies the establishment of norms and rules for the interaction between social actors (North 1990), which gives a greater negotiation capacity to the local stakeholders, also contributing to establish their autonomy as an instance of articulation.

As suggested by Parsons et al. (2018), the future sustainability of the Amazonian forest and the ecosystem services it offers may require management strategies that consider the likelihood of multiyear droughts superimposed on a continued warming trend. Although science can still advance further in this area, we have also assembled enough knowledge to underline the global and regional importance of an intact Amazon region, to support policy making and to keep this sensitive ecosystem functioning. This major challenge requires substantial resources and strategic cross-national planning, and a unique blend of expertise and capacities established in Amazon countries and from international collaboration.

C. Sabel and J. Zeitlin (2011, unpublished manuscript) raise the fundamental challenge in the polycentric governance principle, by articulating the four components that an architecture model of adaptive experimental governance must include. (1) The establishment of a framework of objectives and criteria to measure their achievement, which would be provisionally adopted by a combination of "central" and "local" government units with an obligatory consultation with the most relevant stakeholders. (2) The local units have a wide margin of discretion to pursue these objectives in the manner they deem most appropriate. (3) 
As a condition of this autonomy, local units must regularly report on their actions and participate in accountability processes, where the results are chiefly compared with those units that have used different means to attain the same goals. (4) A representative assembly of public and private stakeholders will periodically review the objectives, criteria, and decision-making procedures. Responding to the problems and alternative solutions that have been revealed in the evaluation processes is key in this approach, because then this cycle will be repeated. In resilience thinking no principle is more important than another, and yet, polycentric governance with its real capacity for experimentation and learning, represents the chief and most urgent challenge.

\section{CONCLUSIONS}

Under resilience thinking, Amazonia is under threat, and biodiversity and redundancy loss in the Amazon biome's multiple dimensions severely limits the long-term sustainability of fundamental ecosystem services' provision in diverse spatial scales (local, regional, and global). At the same time, such loss erodes the system's ability to be resilient to external pressures and changes in its internal dynamics. There is a lack of clarity and coherence in the multiple institutions' set of objectives, and whether or not management and conservation plans are reverting the loss of different diversity components. Land-use planning must include the simultaneous analysis and management of an array of ecosystem services, their interactions, trade-offs, and associated conflicts.

The Amazon region shows two main challenges for a resilience thinking perspective: (1) fragmentation caused by deforestation and its adverse effects on the diversity and ecosystem services provision; (2) cultural and institutional fragmentation of the plans, programs, and projects incompletely designed and implemented in the region. New spatial arrangements of ecosystem services in a combination of temporal and spatial scales must be explored, regardless of whether these configurations happened or not in the historical process of the system. In simple terms, the focus should be on the path of change of the least vulnerable and more resilient spatial arrangements. We emphasize the need for a better comprehension of the interactions between land use, carbon reservoirs, water resources, habitat conservation, human health, and economic development in future scenarios of climate change and land use change.

In addition, the Amazon region presents challenges related to institutional design, the expansion, and strengthening of real participation spaces, and the promotion of social learning. In addition, the recognition of the diversity in cultural, social, and institutional dimensions as well as in programs, plans, and projects in the Amazon region is absent. Land use planning must consider the set of key attributes and properties of socialecological systems, rather than the properties and attributes of natural and social subsystems treated separately. Land use planning must be analyzed and agreed between users and managers. Moreover, it should not attempt to control the variability of the natural subsystem, but instead to generate a greater capacity for adaptation in social-ecological systems to historical, actual, and future variability in nature. It is convenient to favor the processes of change and transformation that enhances the social-ecological systems' adaptability and resilience by considering multiple conditions or potential configurations. The polycentric and adaptive governance is itself a major challenge for this region of social-ecological complexity. Land-use planning must maximize flexibility and multiple options for the future by attempting to respond and adapt to rapid changes in knowledge generation and human valuation.

Responses to this article can be read online at: http://www.ecologyandsociety.org/issues/responses. $\mathrm{php} / 11352$

\section{Acknowledgments:}

The article submitted integrates the initial core group of contributions defined in the Workshop of land use transformation in Latin America (organized by SARAS, SRC, and other institutions) where the idea and focus of the special volume was determined. The authors thank the South American Institute for Resilience and Sustainability Studies (SARAS) for their support in conducting this research, and their funding for this publication.

\section{LITERATURE CITED}

Akimoto, F. 2009. The birth of 'land use planning' in American urban planning. Planning Perspectives 24(4):457-483. https://doi. org/10.1080/02665430903145705

Albert, B., P. de Robert, A.-É. Laques, and F.-M. Le Tourneau. 2011. From Amerindian territorialities to "indigenous lands" in the Brazilian Amazon: the Yanomami and Kayapó cases. Pages 123-141 in C. Aubertin and E. Rodary, editors. Protected areas, sustainable land? Routledge, London, UK.

Angarita-Baéz, J. A., E. Pérez-Miñana, J. E. Beltrán-Vargas, C. A. Ruiz-Agudelo, C. A. Paez, E. Palacios, and S. Willcock. 2017. Assessing and mapping cultural ecosystem services at community level in the Colombian Amazon. International Journal of Biodiversity Science, Ecosystem Services \& Management 13 (1):280-296. https://doi.org/10.1080/21513732.2017.1345981

Arias, F. A., and G. M. Vargas. 2010. Instituciones, gobernanza y sustentabilidad en la política colombiana de ordenamiento territorial municipal. Sociedad y Economía 19:279-304.

Articulação Regional Amazônica (ARA). 2011. La Amazonia y los objetivos de desarollo del Milenio. V. Celentano and M. Vedoveto, editors. ARA Regional, Quito, Ecuador.

Athayde, S., J. R. Stepp, and W. C. Ballester. 2016. Engaging indigenous and academic knowledge on bees in the Amazon: implications for environmental management and transdisciplinary research. Journal of Ethnobiology and Ethnomedicine 12(26):2-19. https://doi.org/10.1186/s13002-016-0093-Z

Aukema, J. E., N. G. Pricope, G. J. Husak, and D. Lopez-Carr. 2017. Biodiversity areas under threat: overlap of climate change and population pressures on the world's biodiversity priorities. PLoS ONE 12(1):e0170615. https://doi.org/10.1371/journal. pone. 0170615

Bamberger, R., and L. C. Kumins. 2005. Oil and gas: supply issues after Katrina and Rita. Congressional Research Service, 
Washington, D.C., USA. [online] URL: https://www.hsdl.org/? abstract\&did $=457103$

Barreto, P., C. Souza Júnior, R. Noguerón, A. Anderson, and R. Salomão. 2006. Human pressure on the Brazilian Amazon forest. World Resources Institute, Washington, D.C., USA. [online] URL: http://www.bibliotecaflorestal.ufv.br/handle/123456789/3426

Berkes, F. 2002. Cross scale institutional linkages: perspectives from the bottom up. Pages 293-321 in E. Ostrom, T. Dietz, N. Dolsak, P. C. Stern, S. Stonich, and E. U. Weber, editors. The drama of the commons. National Academy Press, Washington, D. C., USA.

Betts, R. A., P. M. Cox, M. Collins, P. P. Harris, C. Huntingford, and D. C. Jones. 2004. The role of ecosystem-atmosphere interactions in simulated Amazonian precipitation decrease and forest dieback under global climate warming. Theoretical and Applied Climatology 78:157-175. https://doi.org/10.1007/s00704-004-0050$\underline{\mathrm{y}}$

Biggs, R., M. Schlüter, and M. L. Schoon. 2015. Principles for building resilience: sustaining ecosystem services in socialecological systems. Cambridge University Press, Cambridge, UK. https://doi.org/10.1017/CBO9781316014240

Boyd, E., and C. Folke, editors. 2012. Adapting institutions; governance, complexity and social-ecological resilience. Cambridge University Press, Cambridge, UK.

Bravo, L. C. 2007. Evaluación ambiental estratégica, propuesta para fortalecer la aplicación del ordenamiento ecológico. Caso de estudio de La región Mar de Cortés. Gestión y Política Pública XVI(1):147-170.

Broadbent, E. N., G. P. Asner, M. Keller, D. E. Knapp, P. J. C. Oliveira, and J. N. Silva. 2008. Forest fragmentation and edge effects from deforestation and selective logging in the Brazilian Amazon. Biological Conservation 141(7):1745-1757. https://doi. org/10.1016/j.biocon.2008.04.024

Brudvig, L. A., E. I. Damschen, J. J. Tewksbury, N. M. Haddad, and D. J. Levey. 2009. Landscape connectivity promotes plant biodiversity spillover into non-target habitats. Proceedings of the National Academy of Sciences of the USA 106(23):9328-9332. https://doi.org/10.1073/pnas.0809658106

Brugnach, M., A. Dewulf, C. Pahl-Wostl, and T. Taillieu. 2008. Toward a relational concept of uncertainty: about knowing too little, knowing too differently, and accepting not to know. Ecology and Society 13(2):30. https://doi.org/10.5751/ES-02616-130230

Cabral, A. I. R., and F. L. Costa. 2017. Land cover changes and landscape patterns dynamics in Senegal and Guinea Bissau borderland. Applied Geography 82:115-128. https://doi. org/10.1016/j.apgeog.2017.03.010

Carballal, S., and W. Estellano. 1996. Los orígenes de la estructuración del territorio en Uruguay. Universidad de la República, Maldonado-Uruguay.

Carpenter, S. R., and W. A. Brock. 2008. Adaptive capacity and traps. Ecology and Society 13(2):40. https://doi.org/10.5751/ ES-02716-130240

Caser, U., and C. M. Cebola. 2017. Environmental mediation: an instrument for collaborative decision making in territorial planning. Finisterra 52(104):109-121. https://doi.org/10.18055/ Finis6969

Chapin, III F. S., C. Folke, and G. P. Kofinas. 2009. A framework for understanding change. Pages 3-28 in F. S. Chapin III, G. P. Kofinas, and C. Folke, editors. Principles of ecosystem stewardship: resilience-based natural resource management in a changing world. Springer Science+Business Media, New York, New York, USA. https://doi.org/10.1007/978-0-387-73033-2 1

Cowling, S. A., R. A. Bettsm, P. M. Cox, V. J. Ettwein, C. D. Jones, M. A. Maslin, and S. A. Spall. 2004. Contrasting simulated past and future responses of the Amazon rainforest to atmospheric change. Philosophical Transactions of the Royal Society: Biological Sciences 359:539-547. https://doi.org/10.1098/rstb.2003.1427

Cox, P. M., R. A. Betts, M. Collins, P. P. Harris, C. Huntingford, and C. D. Jones. 2004. Amazonian forest dieback under climatecarbon cycle projections for the 21 st century. Theoretical and Applied Climatology 78:137-156. https://doi.org/10.1007/ s00704-004-0049-4

Cramer, W., A. Bondeau, S. Schaphoff, W. Lucht, B. Smith, and S. Sitch. 2004. Tropical forests and the global carbon cycle: impacts of atmospheric carbon dioxide, climate change and rate of deforestation Philosophical Transactions of the Royal Society B: Biological Sciences 359:331-343. https://doi.org/10.1098/ rstb.2003.1428

Davidson, E. A., A. C. de Araújo, P. Artaxo, J. K. Balch, I. F. Brown, M. M. C. Bustamante, M. T. Coe, R. S. DeFries, M. Keller, M. Longo, J. W. Munger, W. Schroeder, B. S. Soares-Filho, C. M. Souza, and S. C. Wofsy. 2012. The Amazon basin in transition. Nature 481:321-328. https://doi.org/10.1038/nature10717

de Dios, F. F. 2013. Colonización y tierras públicas. II Congreso Nacional de Derecho Agrario Provincial. October 4-5. Facultad de Ciencias Jurídicas y Sociales, Univeresidad Nacional de La Plata, Buenos Aires, Argentina. [online] URL: http://sedici.unlp.edu.ar/ bitstream/handle/10915/39461/Documento completo.pdf? sequence $=1 \&$ is Allowed $=\mathrm{y}$

Driscoll, P. A., and D. Galland. 2014. Young academics special theme issue: perspectives on planning shifts, challenges and methodologies. Planning, Practice \& Research 29(3):217-219. https://doi.org/10.1080/02697459.2014.929834

Durán-Rocca, L. 2006. La malla urbana en la ciudad colonial iberoamericana. Apuntes. Revista De Estudios Sobre Patrimonio Cultural 19(1).

Durán-Rocca, L. 2009. Apuntes sobre el urbanismo en Brasil colonial. DEARQ. Revistas Uniandes 4:141-154. https://doi. org/10.18389/dearq4.2009.18

Erazo, J. 2010. Constructing indigenous subjectivities: economic collectivism and identity in the Ecuadorian Amazon. Development and Change 41(6):1017-1039. https://doi.org/10.1111/ j.1467-7660.2010.01669.x

Fearnside, P. M. 2005. Deforestation in Brazilian Amazonia: history, rates, and consequences. Conservation Biology 19 (3):680-688. https://doi.org/10.1111/j.1523-1739.2005.00697.x

Foley, J. A, G. P. Asner, M. Heil Costa, M. T. Coe, R. DeFries, H. K. Gibbs, E. A. Howard, S. Olson, J. Patz, N. Ramankutty, and P. Snyder. 2007. Amazonia revealed: forest degradation and 
loss of ecosystem goods and services in the Amazon Basin. Frontiers in Ecology and the Environment 5(1):25-32. https://doi. org/10.1890/1540-9295(2007)5[25:arfdal]2.0.co;2

Foley, J. A., R. DeFries, G. P. Asner, C. Barford, G. Bonan, S. R. Carpenter, F. S. Chapin, M. T. Coe, G. C. Daily, H. K. Gibbs, J. H. Helkowski, T. Holloway, E. A. Howard, C. J. Kucharik, C. Monfreda, J. P. Patz, I. C. Prentice, N. Ramankutty, and P. K. Snyder. 2005. Global consequences of land use. Science 309:570-574. https://doi.org/10.1126/science.1111772

Folke, C. 2016. Resilience (republished). Ecology and Society 21 (4):44. https://doi.org/10.5751/ES-09088-210444

García-Márquez, J. R., T. Krueger, C. P. Páez, C. A. RuizAgudelo, P. Bejarano, T. Muto, and F. Arjona. 2017. Effectiveness of conservation areas for protecting biodiversity and ecosystem services: a multi-criteria approach. International Journal of Biodiversity Science, Ecosystem Services \& Management 13 (1):1-13 https://doi.org/10.1080/21513732.2016.1200672

Godar, J., T. A. Gardner, E. J. Tizado, and P. Pacheco. 2014 . Actorspecific contributions to the deforestation slowdown in the Brazilian Amazon. Proceedings of the National Academy of Sciiences of the USA 111:15591-15596. https://doi.org/10.1073/ pnas. 1322825111

Gondim, M. G., G. de Goés, and T. de Jesus-Pinto. 2017. Protected areas in the Amazon: forest management, conflict and social participation. Acta Scientiarum. Humam and Social Sciences (39) 1:63-70.

Gray, C. L., R. E. Bilsborrow, J. L. Bremner, and F. Lu. 2008. Indigenous land use in the Ecuadorian Amazon: a cross-cultural and multilevel analysis. Human Ecology 36(1):97-109. http://dx. doi.org/10.1007/s10745-007-9141-6

Haddad, N. M., L. A. Brudvig, J. Clobert, K. F. Davies, A. Gonzalez, R. D. Holt, T. E. Lovejoy, J. O. Sexton, M. P. Austin, C. D. Collins, et al. 2015. Habitat fragmentation and its lasting impact on Earth's ecosystems. Science Advances 1(2):e1500052. https://doi.org/10.1126/sciadv.1500052

Hannah, L. 2008. Protected areas and climate change. Annals of the New York Academy of Sciences 1134:201-212. https://doi. org/10.1196/annals.1439.009

Hernández, Y. 2010. El ordenamiento territorial y su construcción social in Colombia: ¿un instrumento para el desarrollo sustentable? Revista Colombiana de Geografía 19:97-109.

Holling, C. S. 1973. Resilience and stability of ecological systems. Annual Review of Ecological Systems 4:1-23. https://doi. org/10.1146/annurev.es.04.110173.000245

Holling, C. S., F. Berkes, and C. Folke. 2000. Science, sustainability, and resource management. Pages 342-362 in F. Berkes and C. Folke, editors. Linking social and ecological systems: management practices and social mechanisms for building resilience. Cambridge University Press, Cambridge, UK.

Instituto Nacional de Pesquisas Espaciais (INPE). 2011. Monitoramento do Desmatamento da Floresta Amazônica Brasileira por Satélite. INPE, São José dos Campos, Brazil. [online] URL: http://www.obt.inpe.br/OBT/assuntos/programas/ amazonia/prodes
International Rivers. [date unknown]. The state of the world's rivers. International Rivers, Oakland, California, USA. [online] URL: http://tryse.net/googleearth/irivers-dev3/

Jakovac, C. C., M. Peña-Claros, T. W. Kuyper, and F. Bongers. 2015. Loss of secondary-forest resilience by land-use intensification in the Amazon. Journal of Ecology 103:67-77. https://doi.org/10.1111/1365-2745.12298

Jiménez-Muñoz, J. C., J. A. Sobrino, C. Mattar, and Y. Malhi. 2013. Spatial and temporal patterns of the recent warming of the Amazon forest. Journal of Geophysical Research: Atmospheres 118:5204-5215. https://doi.org/10.1002/jgrd.50456

Josse, C., B. Young, R. Lyons-Smyth, T. Brooks, A. Frances, P. Comer, P. Petry, H. Balslev, B. Bassuner, B. Goettsch, J. Hak, P. Jørgensen, D. Larrea-Alcázar, G. Navarro, S. Saatchi, A. Sanchez de Lozada, J. C. Svenning, L. A. Tovar, and A. Moscoso. 2013. Decision-making inputs for the conservation of the western Amazon basin. Ecología Aplicada 12(1):45-65.

Kay, C. 2008. Latin America's rural transformation: unequal development and persistent poverty. Pages $24-48$ in R. L. Harris and J. Nef, editors. Capital, power, and inequality in Latin America and the Caribbean. Rowman \& Littlefield, Lanham, Maryland, USA.

Kerr, J. T., and M. Ostrovsky. 2003. From space to species: ecological applications for remote sensing. Trends in Ecology and Evolution 18:299-305. https://doi.org/10.1016/S0169-5347(03) $\underline{00071-5}$

Laterra, P., and L. A. Nahuelhual. 2014. Internalización de los servicios ecosistémicos en el ordenamiento territorial rural: bases conceptuales y metodológicas. Pages 86-106 in J. M. Paruelo, E. G. Jobbágy, P. Laterra, H. Dieguez, editors. Ordenamiento territorial rural: conceptos, métodos y experiencias. Food and Agriculture Organization, Rome, Italy.

Laurance, W. F. 2007. Have we overstated the tropical biodiversity crisis? Trends in Ecology \& Evolution 22:65-70. https://doi. org/10.1016/j.tree.2006.09.014

Levitsky, S., and M. V. Murillo. 2013. Lessons from Latin America: building institutions on weak foundations. Journal of Democracy 24:93-107. https://doi.org/10.1353/jod.2013.0031

Lewis, S. L., P. M. Brando, O. L. Phillips, G. M. F. van der Heijden, and D. Nepstad. 2011. The 2010 Amazon drought. Science 331:554. https://doi.org/10.1126/science. 1200807

Lewis, S. L., Y. Malhi, and O. L. Phillips. 2004. Fingerprinting the impacts of global change on tropical forests. Philosophical Transactions of the Royal Society B: Biological Sciences 359:437-462. https://doi.org/10.1098/rstb.2003.1432

Lu, F. 2010. Patterns of indigenous resilience in the Amazon: a case study of Huaorani hunting in Ecuador. Journal of Ecological Anthropology 14(1):5-21. https://doi.org/10.5038/2162-4593.14.1.1

Maes, J., B. Egoh, L. Willemen, C. Liquete, P. Vihervaara, J. P. Schägner, B. Grizzetti, E. G. Drakou, A. L. Notte, G. Zulian, F. Bouraoui, M. L. Paracchini, L. Braat, and G. Bidoglio. 2012. Mapping ecosystem services for policy support and decision making in the European Union. Ecosystem Services 1:31-39. https://doi.org/10.1016/j.ecoser.2012.06.004 
Magnuszewski, P., K. Ostasiewicz, R. Chazdon, C. Salk, M. Pajak, J. Sendzimir, and K. Andersson. 2015. Resilience and alternative stable states of tropical forest landscapes under shifting cultivation regimes. PLoS ONE 10(9): e0137497. https:// doi.org/10.1371/journal.pone.0137497

Mann, M. L., R. K. Kaufmann, D. M. Bauer, S. Gopal, J. G. Baldwin, and M. C. Vera-Diaz. 2012. Ecosystem service value and agricultural conversion in the Amazon: implications for policy intervention. Environmental and Resource Economics 53:279-295. https://doi.org/10.1007/s10640-012-9562-6

Marengo, J. A., L. S. Borma, D. A. Rodriguez, P. Pinho, W. R. Soares, and L. M. Alves. 2013. Recent extremes of drought and flooding in Amazonia: vulnerabilities and human adaptation. American Journal of Climate Change 2:87-96. https://doi. org/10.4236/ajcc.2013.22009

Marquardt, K., R. Milestad, and L. Salomonsson. 2013. Improved fallows: a case study of an adaptive response in Amazonian swidden farming systems. Agriculture and Human Values 30:417-428. https://doi.org/10.1007/s10460-012-9415-5

Massiris, A. 2012. Procesos de ordenamiento in América Latina y Colombia. Universidad Nacional De Colombia, Facultad de Artes, Maestría in Ordenamiento Urbano-Regional, Bogotá D. C., Colombia.

Massiris, A. 2017. Cambios recientes in las políticas de ordenamiento territorial in América Latina. Universidad Nacional Autónoma de México, Mexico City, Mexico.

May, R. M., S. A. Levin, and G. Sugihara. 2008. Complex systems: ecology for bankers. Nature 451:893-894. https://doi. org/10.1038/451893a

McGee, S. 2011. Chasing Goldman Sachs: how the master of the universe melted Wall Street. Random House, New York, New York, USA.

McGuire, J. L., J. J. Lawler, B. H. Mcrae, T. A. Nuñez, and D. M. Theobald. 2016. Achieving climate connectivity in a fragmented landscape. Proceedings of the National Academy of Sciences of the USA 113:7195-7200. https://doi.org/10.1073/pnas.1602817113

Michielsen, T. O. 2013. The distribution of energy-intensive sectors in the USA. Journal of Economic Geography 13:871-888. https://doi.org/10.1093/jeg/lbs045

Miller, S. D., M. L. Goulden, L. R. Hutyra, M. Keller, S. R. Saleska, S. C. Wofsy, A. M. Silva Figueira, H. R. da Rocha, and P. B. De Camargo. 2011. Reduced impact logging minimally alters tropical rainforest carbon and energy exchange. Proceedings of the National Academy of Sciences of the USA 108 (48):19431-19435. https://doi.org/10.1073/pnas.1105068108

Ministerio de Ambiente y Desarrollo Rural (MADS). 2015. Visión Amazonia. Ministerio de Ambiente y Desarrollo Sostenible Bogotá, Brazil. [online] URL: http://www.minambiente.gov.co/ images/Atencion y particpacion al ciudadano/consultas publicas 2015/ viceministerio/Resumen-VisionAmazonia-WEB.pdf

Mittermeier, R. A., C. G. Mittermeier, T. M. Brooks, J. D. Pilgrim, W. R. Konstant, G. A. B. da Fonseca, and C. Kormos. 2003. Wilderness and biodiversity conservation. Proceedings of the National Academy of Sciences of the USA 100:10309-10313. https://doi.org/10.1073/pnas. 1732458100
Müller-Hansen, F., M. F. Cardoso, E. L. Dalla-Nora, J. F. Donges, J. Heitzig, J. Kurths, and K. Thonicke. 2017. A matrix clustering method to explore patterns of land-cover transitions in satellitederived maps of the Brazilian Amazon. Nonlinear Processes in Geophysics 24:113-123. https://doi.org/10.5194/npg-24-113-2017

Needham, B., and E. Buitelaar. 2012. Rights, responsibilities and equity in land use planning. The 6 th IAPLPR Conference, Belfast, 8-10 February. Town Planning Review 83(6). Liverpool University Press, Liverpool, UK. https://doi.org/10.3828/tpr.2012.44

Nemani, R. R., C. D. Keeling, H. Hashimoto, W. M. Jolly, S. C. Piper, C. J. Tucker, R. B. Myneni, and S. W. Running. 2003. Climate-driven increases in global terrestrial net primary production from 1982 to 1999 . Science 300:1560-1563. https://doi. org/10.1126/science. 1082750

Nepstad, D., P. Lefebvre, U. Lopes da Silva, J. Tomasella, P. Schlesinger, L. Solórzano, P. Moutinho, D. Ray, and J. Guerreira Benito. 2004. Amazon drought and its implications for forest flammability and tree growth: a basin-wide analysis. Global Change Biology 10:704-717. https://doi.org/10.1111/ j.1529-8817.2003.00772.x

Nepstad, D., D. McGrath, C. Stickler, A. Alencar, A. Azevedo, B. Swette, T. Bezerra, M. DiGiano, J. Shimada, R. Seroa da Motta, et al. 2014. Slowing amazon deforestation through public policy and interventions in beef and soy supply chains. Science 344:1118-1123. https://doi.org/10.1126/science.1248525

Nepstad, D. C., C. M. Stickler, B. Soares-Filho, and F. Merry. 2008. Interactions among Amazon land use, forests and climate: prospects for a near-term forest tipping point. Philosophical Transactions of the Royal Society B: Biological Sciences 363:1737-1746. https://doi.org/10.1098/rstb.2007.0036

Neugarten, R., P. Ceotto, N. Acero, B. Coutinho, R. FloresGutierrez, M. Hierholzer, T. Kasecker, K. Koenig, J. Ledezma, R. Pinheiro, W. Turner, and T. Wright. 2017. Amazonia: mapping essential natural capital. Conservation International Foundation, Arlington, Virginia, USA. https://doi.org/10.13140/RG.2.2.30544.40961

Nijnik, M., D. Miller, A. Nijnik, S. Fiorini, N. Vogt, E. Brondizio, and J. Morrice. 2011. Public participation for planning the sustainable use of natural resources and landscape change: methodology development. International Journal of Interdisciplinary Social Sciences 5(11):1833-1882. https://doi.org/10.18848/1833-1882/ CGP/v05i11/51954

Nobre, A. D. 2014. The future climate of Amazonia: scientific assessment report. Sponsored by Earth System Science Center (CCST)-National Institute of Space Research (INPE), National Institute of Amazonian Research (INPA), and Articulación Regional Amazônica (ARA). São José dos Campos, Brazil. [onlne] URL: https://wwf.panda.org/?232041/The-Future-Climateof-Amazonia

Nobre, C. A., G. Sampaio, L. S. Borma, J. C. Castilla-Rubio, J. S. Silva, and M. Cardoso. 2016. Land-use and climate change risks in the Amazon and the need of a novel sustainable development paradigm. Proceedings of the National Academy of Sciences of the USA 113:10759-10768. https://doi.org/10.1073/ pnas. 1605516113

North, D. C. 1990. Institutions, institutional change and economic performance. Cambridge University Press, Cambridge, UK. https://doi.org/10.1017/CBO9780511808678 
Ostrom, E., J. Burger, C. B. Field, R. B. Norgaard, and D. Policansky. 1999. Revisiting the commons: local lessons, global challenges. Science 284:278-282. https://doi.org/10.1126/ science. 284.5412 .278

Parsons, L. A., S. LeRoy, J. T. Overpeck, M. Bush, G. M. Cárdenes-Sandí, and S. Saleska. 2018. The threat of multi-year drought in Western Amazonia. Water Resources Research 54:5890-5904. https://doi.org/10.1029/2017WR021788

Pasquis, R. 2005. Causas e conseqüencias do avanco da soja na Amazonia Legal: Elaborando a arvore causal. Embrapa Oriental, Belem, Brazil.

Pasquis, R. 2006a. Mercado y medio ambiente: el caso de la soya en la Amazonia brasileña. Iconos 25:47-56. https://doi. org/10.17141/iconos.25.2006.168

Pasquis, R. 2006b. Desequilibrios territoriales en la Amazonia brasileña: el caso de la frontera de la soya. XXVII Congreso Nacional y XII Congreso Internacional de Geografia: El aporte de la Geografía en la Superación de los Desequilibrios Territoriales y Sociales, mesa: La lógica del mercado y el ordenamiento del territorio. Sociedad Chilena de Ciencias Geográficas, 17-20 de octubre 2006, Concepción, Chile.

Perz, S. G., L. Cabrera, L. A. Carvalho, J. Castillo, and G. Barnes. 2010. Global economic integration and local community resilience: road paving and rural demographic change in the southwestern Amazon. Rural Sociology 75(2):300-325. https:// doi.org/10.1111/j.1549-0831.2009.00008.x

Phalan, B., M. Bertzky, S. H. Butchart, P. F. Donald, J. P. Scharlemann, A. J. Stattersfield, and A. Balmford. 2013. Crop expansion and conservation priorities in tropical countries. PLoS ONE 8(1):51759. https://doi.org/10.1371/journal.pone.0051759

Ponce-Campos, G. E., M. S. Moran, A. Huete, Y. Zhang, C. Bresloff, T. E. Huxman, D. Eamus, D. D. Bosch, A. R. Buda, S. A. Gunter, T. H. Scalley, S. G. Kitchen, M. P. McClaran, W. H. McNab, D. S. Montoya, J. A. Morgan, D. P. C. Peters, E. J. Sadler, M. S. Seyfried, and P. J. Starks. 2013. Ecosystem resilience despite large-scale altered hydroclimatic conditions. Nature 494:349-352. https://doi.org/10.1038/nature11836

Posey, D. A., and M. J. Balick. 2006. Human impacts on Amazonia: the role of traditional ecological knowledge in conservation and development. Columbia University Press, New York, New York, USA. https://doi.org/10.7312/pose10588

RAISG (Amazonian Network of Georeferenced Socioenvironmental Information). 2013. Amazonia under pressure. RAISG, São Paulo, Brazil. [online] URL: https://www. amazoniasocioambiental.org/en/publication/amazonia-under-pressure/

RAISG (Amazonian Network of Georeferenced Socioenvironmental Information). 2015. Deforestation in the Amazon from 1970 to 2013. RAISG, São Paulo, Brazil. [online] URL: https://infoamazonia.org/en/2015/10/raisg-deforestation-in-the-amazonfrom-1970-to-2013/

Rama, A. 1984. La ciudad letrada. Ediciones Arca, Montevideo, Uruguay.

Ramírez, A. G., A. Cruz, N. Morales, and A. I. Monterroso. 2015. The territorial ecological zoning environmental policy instrument for local development planning. Estudios Sociales 48(26):71-97.
Reardon, S. 2018. FARC and the forest: peace is destroying Colombia's jungle-and opening it to science. Nature 558:169-170. https://doi.org/10.1038/d41586-018-05397-2

Recio, M. E. 2017. Latin America and Caribbean. Current Developments in Carbon \& Climate Law 11(2):160-161. https:// doi.org/10.21552/cclr/2017/2/13

Rice, J., V. Rodríguez Osuna, M. E. Zaccagnini, E. Bennet, D. Buddo, N. Estrada-Carmona, K. Garbach, N. Vogt, and M. P. Barral. 2018. Setting the scene. Pages 1-52 in J. Rice, C. S. Seixas, M. E. Zaccagnini, M. Bedoya-Gaitán, and N. Valderrama, editors. The regional assessment report on biodiversity and ecosystem services for the Americas. Secretariat of the Intergovernmental Science-Policy Platform on Biodiversity and Ecosystem Services, Bonn, Germany.

Rocha, J. C., G. Peterson, Ö. Bodin, and S. Levin. 2018. Cascading regime shifts within and across scales. Science 362 (6421):1379-1383. https://doi.org/10.1126/science.aat7850

Rosselli, A., M. C. Díazgranados, J. S. Usma, F. Trujillo, C. A. García. E. Valenzuela, P. Herron, S. Espinosa, J. Botero, A. M. Roldan, J. G. Ramírez, and V. Puentes, editors. 2014. Manejo participativo de recursos biológicos y pesqueros, herramienta para la conservación y uso sostenible del patrimonio natural de Colombia. Pontificia Universidad Javeriana, Bogotá D.C. November 5 a 7 de 2013. Conservación Internacional Colombia, Fondo Acción Programa Conservación para el Desarrollo, AUNAP, Programa Bioredd + USAID, Fundación Omacha, Agencia Presidencial de Cooperación Internacional - APC Colombia \& WWF, Colombia.

Rudel, T. K., D. Bates, and R. Machinguiashi. 2002. Ecologically noble Amerindians? Cattle ranching and cash cropping among Shuar and colonists in Ecuador. Latin American Research Review 37(1):144-159.

Saatchi, S. S., R. A. Houghton, R. C. dos Santos Alvalá, J. V. Soares, and Y. Yu. 2007. Distribution of aboveground live biomass in the Amazon basin. Global Change Biology 13 (4):816-837. https://doi.org/10.1111/j.1365-2486.2007.01323.x

Salazar, L. F., C. A. Nobre, and M. D. Oyama. 2007. Climate change consequences on the biome distribution in tropical South America. Geophysical Research Letters 34(9). https://doi. org/10.1029/2007GL029695

Scheffer, M., J. E. Bolhuis, D. Borsboom, T. G. Buchman, S. M. Gijzel, D. Goulson, J. E. Kammenga, B. Kemp, I. A. van de Leemput, S. Levin, et al. 2018. Quantifying resilience of humans and other animals. Proceedings of the National Academy of Sciences of the USA 115(47):11883-11890. https://doi. org/10.1073/pnas.1810630115

Shoo, L. P., C. Storlie, J. Vanderwal, J. Little, and S. E. Williams. 2011. Targeted protection and restoration to conserve tropical biodiversity in a warming world. Global Change Biology 17:186-193. https://doi.org/10.1111/j.1365-2486.2010.02218.x

Silvestrini, R. A., B. S. Soares-Filho, D. Nepstad, M. Coe, H. Rodrigues, and R. Assunção. 2011. Simulating fire regimes in the Amazon in response to climate change and deforestation. Ecological Applications 21(5):1573-1590. https://doi. org/10.1890/10-0827.1 
Simmons, C., R. Walker, S. Perz, E. Arima, S. Aldrich, and M. Caldas. 2016. Spatial patterns of frontier settlement: balancing conservation and development. Journal of Latin American Geography 15:33-58. https://doi.org/10.1353/lag.2016.0011

Simmons, C. S., L. Famolare, M. N. Macedo, R. T. Walker, M. T. Coe, B. Scheffers, E. Arima, R. Munoz-Carpena, D. Valle, C. Fraisse, P. Moorcroft, M. Diniz, M. Diniz, C. Szlafsztein, R. Pereira, C. Ruiz, G. Rocha, D. Juhn, L. Otávio do Canto Lopes, M. Waylen, A. Antunes, and Y. M. Galvan. 2018. Science in support of Amazonian conservation in the 21st century: the case of Brazil. Biotropica 50:850-858. https://doi.org/10.1111/ btp. 12610

Simonsen, S. H., R. O Biggs, M. Schlüter, M. Schoon, E. Bohensky, G. Cundill, V. Dakos, T. Daw, K. Kotschy, A. Leitch, A. Quinlan, G. Peterson, and F. Moberg. 2016. Poniendo en práctica el pensamiento resiliente: Siete principios para desarrollar la resiliencia en los sistemas socio-ecológicos. Stockholm Resilience Centre, Stockholm, Sweden. [online] URL: http:// applyingresilience.org/wp-content/uploads/sites/2/2016/04/ Applying resilience thinking SP aktiv.pdf

Skole, D., and C. Tucker. 1993. Tropical deforestation and habitat fragmentation in the Amazon: satellite data from 1978 to 1988. Science 260(5116):1905-1910. https://doi.org/10.1126/ science.260.5116.1905

Soares-Filho, B., P. Moutinho, D. Nepstad, A. Anderson, H. Rodrigues, R. Garcia, L. Dietzsch, F. Merry, M. Bowman, L. Hissa, R. Silvestrini, and C. Maretti. 2010. Role of Brazilian Amazon protected areas in climate change mitigation. Proceedings of the National Academy of Sciences of the USA 107 (24):10821-10826. https://doi.org/10.1073/pnas.0913048107

Soares-Filho, B. S., D. C. Nepstad, L. M. Curran, G. C. Cerqueira, R. A. Garcia, C. A. Ramos, E. Voll, A. McDonald, P. Lefevbre, and P. Schlesinger. 2006. Modelling conservation in the Amazon basin. Nature 440(7083):520-523. https://doi.org/10.1038/ $\underline{\text { nature } 04389}$

Stimson, R. J. 2017. Some challenges for regional science research. Investigaciones Regionales-Journal of Regional Research 36:11-34.

Tambosi, L. R., A. C. Martensen, M. C. Ribeiro, and J. P. Metzger. 2014. A framework to optimize biodiversity restoration efforts based on habitat amount and landscape connectivity. Restoration Ecology 22(2):169-177. https://doi.org/10.1111/rec.12049

Tapia-Armijos, M. F., J. Homeier, C. I. Espinosa, C. Leuschner, and M. de La Cruz. 2015. Deforestation and forest fragmentation in south Ecuador since the 1970s: losing a hotspot of biodiversity. PloS ONE 10(9):e0142359. https://doi.org/10.1371/journal. pone. 0133701

United Nations Development Programme and Inter-American Development Bank. 1991. Nuestra propia agenda sobre desarrollo $y$ medio ambiente. Banco Interamericano de Desarrollo, Washington, D.C., USA. [online] URL: https://searchworks. stanford.edu/view/1963866

Vedovato, L. B., M. G. Fonseca, E. Arai, L. O. Anderson, and L. E. O. Aragão. 2016. The extent of 2014 forest fragmentation in the Brazilian Amazon. Regional Environmental Changes 16 (8):2485-2490. https://doi.org/10.1007/s10113-016-1067-3

Walker, B. H., and D. Salt. 2006. Resilience thinking: sustaining ecosystems and people in a changing world. Island, Washington, D.C., USA.

Walker, R., R. Defries, M. D. C. Vera-Diaz, Y. Shimabukuro, and A. Venturieri. 2009. The expansion of intensive agriculture and ranching in Brazilian Amazonia. Pages 61-81 in M. Keller, M. Bustamante, J. Gash, and P. S. Dias, editors. Amazonia and global change. American Geophysical Union, Washington, D.C., USA. https://doi.org/10.1029/2008GM000724

Walker, R., and C. Simmons. 2018. Endangered Amazon: an indigenous tribe fights back against hydropower development in the Tapajós Valley. Environment: Science and Policy for Sustainable Development 60:4-15. https://doi.org/10.1080/00139$\underline{157.2018 .1418994}$

Walker, W. E., M. Haasnoot, and J. H. Kwakkel. 2013. Adapt or perish: a review of planning approaches for adaptation under deep uncertainty. Sustainability 5(3):955-979. https://doi. org/10.3390/su5030955

Weyland, F., M. E. Mastrangelo, A. D. Auer, M. P. Barral, L. Nahuelhual, A. Larrazábal, A. F. Parera, L. M. Berrouet Cadavid, C. P. López-Gómez, and C. Villegas Palacio. 2019. Ecosystem services approach in Latin America: from theoretical promises to real applications. Ecosystem Services 35:280-293. https://doi. org/10.1016/j.ecoser.2018.11.010

Wong-González, P . 2012. Ordenamiento ecológico y ordenamiento territorial: retos para la gestión del desarrollo regional sustentable in el siglo XXI. Estudios Sociales Número Especial. XX Aniversario. 11-39.

Zambrano, F., and O. Bernard. 1993. Ciudad y Territorio. Tercer Mundo Editores, Bogotá, Brazil. https://doi.org/10.4000/books. ifea. 2083

Zemp, D. C., C.-F. Schleussner, H. M. J. Barbosa, M. Hirota, V. Montade, G. Sampaio, A. Staal, L. Wang-Erlandsson, and A. Rammig. 2017. Self-amplified Amazon forest loss due to vegetation-atmosphere feedbacks. Nature Communications 8:14681. https://doi.org/10.1038/ncomms14681

Zolli, A., and A. M. Healy. 2012. Resilience: why things bounce back. Simon \& Schuster, New York, New York, USA. 